Biodiversity and Conservation

December 2009, Volume 18 (14), Pages 3759-3784

http://dx.doi.org/10.1007/s10531-009-9678-3

(c) 2009 Springer. Part of Springer Science+Business

Media

The original publication is available at http://www.springerlink.com
Archimer, archive institutionnelle de l'Ifremer http://www.ifremer.fr/docelec/

\title{
Diversity and composition of macrobenthic community associated with sandy shoals of the Louisiana continental shelf
}

\author{
Stanislas Dubois ${ }^{1,2,3,{ }^{*}}$, Carey G. Gelpi Jr. ${ }^{1}$, Richard E. Condrey ${ }^{1}$, Mark A. Grippo ${ }^{2}$ and \\ John W. Fleeger ${ }^{2}$
}

\author{
${ }^{1}$ Department of Oceanography and Coastal Sciences, Louisiana State University, Energy Coast and Environment \\ Building, Baton Rouge, LA 70803, USA \\ ${ }^{2}$ Department of Biological Sciences, Louisiana State University, 202 Life Sciences Building, Baton Rouge, LA \\ 70803-1715, USA \\ ${ }^{3}$ Present address : IFREMER, DYNECO Ecologie Benthique, Technopole de Brest-Iroise, BP 70, 29280 \\ Plouzané, France
}

\author{
*: Corresponding author: Dubois S., phone: +33 2982249 18, fax: +33 298224548 25, email address : \\ sdubois@ifremer.fr
}

\begin{abstract}
:
Along the Louisiana, USA continental shelf, sandy shoals are shallow, possibly oxygen-rich "islands" surrounded by deeper muddy deposits prone to hypoxia. Shoals also contain significant quantities of fine sand that may be mined in the future for coastal restoration. The ecological role of shoals remains poorly understood and we hypothesized that shoals provide critical habitat for benthic invertebrates. Using Ship Shoal as a model system, we assessed the diversity and structure of macrobenthic assemblages and how community structure varies with season and environmental parameters. High biomass (averaging $26.7 \mathrm{~g} \mathrm{~m}^{-2}$ ) and high diversity (161 species) of macrobenthos was found in 2006. Polychaetes (45\%-72 species) and crustaceans comprised most of the species (28\%-46 species); spionids and amphipods dominated the polychaete and crustacean groups respectively, both in terms of number of species and abundances. Sharp decreases in diversity, abundance and biomass occurred from spring to autumn. Species diversity and total abundance significantly increased with decreasing sediment grain size and increasing bottom water dissolved oxygen. Across seasons, mole crabs Albunea paretii and amphioxus Branchiostoma floridae typified the community and contributed most of the biomass. The polychaetes Nephtys simoni, Neanthes micromma, Dispio uncinata, Mediomastus californiensis and Magelona sp. A, the amphipod Acanthohautorius sp. A and the burrowing shrimp Ogyrides alphaerostris also contributed to variation in community composition. Cluster analyses quantified seasonal variation, mainly based on sharp decreases in abundance, as well as spatial differences in species composition oriented along both east-west and north-south gradients. Variation in benthic assemblages was correlated with water depth and sediment characteristics (mean grain size and percentage of gravel-sized shell debris). We conclude that Ship Shoal is an unrecognized biodiversity hotspot and a hypoxia refuge compared to the immediate surrounding area where the benthic community is affected by seasonal hypoxia events and we discuss how sand-mining may influence this community.
\end{abstract}

Keywords: Biodiversity hotspot - Continental shelf - Gulf of Mexico - Hypoxia refuge - Louisiana Sand bank - Shallow habitat 


\section{Introduction}

Recently, sandy shoals of the US continental shelf have received increased attention because they have been identified as potential exploitable sand deposits (Drucker et al. 2004). This is especially true for the Louisiana coast where a single shoal (Ship Shoal) is considered one of the largest sand sources in the Gulf of Mexico (Drucker et al. 2004), containing 1.6 billion cubic yards of fine sand intended for beach reinforcement and coastal stabilization projects designed to prevent coastal erosion due to storm damages and prevent wetland loss due to anthropogenic disturbances that induce sea-level rise (Michel et al. 2001). This increased interest in shoals highlights the observation that the benthic and nektonic composition of shoals is less well studied than other continental shelf environments (Brooks et al. 2006). Faunal composition may be important to predicting recovery after sand mining and to understanding ecological relationships on shoals. For example, benthic invertebrates are directly related to the sediment they inhabit (Gray 1974; Snelgrove and Butman 1994), and any sand-mining activity or associated human-related change in sediment features may negatively affect the resident community and consequently impact trophic relationships 
within these communities. It is thus of primary importance to identify and characterize

75 macroinfaunal benthic assemblages associated with potential sand-mining sites.

The macrobenthos of some Louisiana - Texas shoals (i.e. Sabine and Healds Shoals) have been recently investigated (Cheung et al. 2006) but these studies and a recent macrobenthic survey of Louisiana in-shore and off-shore waters (Baustian 2005) did not include Ship Shoal, partly because its shallow depth has discouraged access by large research 80 vessels. A habitat specific survey of the epifauna and fish fauna of several sandbanks off the Welsh coast (UK) revealed that sandbanks were characterized by a unique (although low diverse) epifauna and fish assemblages (Kaiser et al. 2004). But the authors also stated that sandbanks are difficult habitats to sample and may have been overlooked by biologists. Ship Shoal's benthic species assemblages might be used as a food source for numerous fishes or 85 large crustaceans that permanently or temporarily forage on this shoal, as suggested by Thouzeau et al. (1991) for the Georges Bank, northeast coast of the United States. In addition, because of its location in the north central Gulf of Mexico, and unlike the continental shelf off of western Florida, Ship Shoal is surrounded by muddy soft-bottoms affected by seasonal hypoxia events that causes drastic decreases in abundances of benthic 90 species inhabiting this "dead zone" (Rabalais et al. 1994; Justić et al. 1996). It is unknown whether benthic populations living on Ship Shoal are affected by hypoxic events. It is possible that Ship Shoal may serve as an hypoxia refuge for benthic populations or as a faunal reserve from which larvae, juveniles and/or adults may disperse and recolonize the surrounding hypoxic area when normoxia returns.

The overall objectives for this study are thus to better understand the potential role Ship Shoal plays in the Louisiana's coastal ecosystem, and to address the potential effects of sand-mining on the benthic community. Our approach is to describe spatial and seasonal variations in diversity and structure of macrobenthic assemblages associated with Ship Shoal 
over a relatively fine-scale latitudinal and longitudinal gradient and to link community 2100 patterns with variation in environmental parameters.

On a broader scale, there is an increasing awareness of the ecological implications of sand and gravel mining from land, river, and coastal-ocean systems (i.e. Peckenham et al. 2009; Pempel and Church 2009; Zeppelini et al. 2009). Though sand mining has historically been associated with road and building construction, it has become one of the preferred 105 approaches in beach nourishment projects, despite the likelihood of broad ecological impacts on both the extracted and receiving sites and the ephemeral beach-restoration expectations (Defeo et al. 2009). Demands on coastal-ocean sand supplies are likely to increase as human occupation of the coastal zone and sea level continue to rise, and land-based sand-supplies decline. Lessons learned from careful studies of the impacts of current coastal-ocean sand mining operations could prove valuable as extractions of other marine minerals begin and increase (e.g., Rona 2008).

\section{Material and methods}

Study site

Samples were taken from 21 stations on Ship Shoal, located in the north-central Gulf of Mexico approximately $20 \mathrm{~km}$ off-shore from Terrebonne Bay and Isles Dernieres, 120 Louisiana $\left(28^{\circ} 54.092 \mathrm{~N}, 91^{\circ} 00.989 \mathrm{~W}\right)$. The shape of this shoal is elongated, parallel to the shore. It spans a $50 \mathrm{~km}$ distance along the east-west dimension and 1 to $10 \mathrm{~km}$ along the north-south dimension (Figure 1). Based on depth contours available on existing sea charts, stations were chosen according to an east-west distribution with three main north-south 
(latitude) transects, one in the east (stations 15-16-17), one in the west (stations 23-22-21),

125 and one in the middle (stations 24-25-26). Other stations were distributed along the spine (longitude) of this sandy shoal in three main groups: east stations from station 18 to station 13, middle stations from station 12 to station 09 and 10, and west stations from stations 07 and 08 to station 01 and 19 . The general bathymetry of the shoal is related to east-west and north-south gradients: the western region is the shallowest (ca. $4 \mathrm{~m}$ ) and the depth increase toward the east (ca. $10 \mathrm{~m})$. A north-south transect across the shoal shows that the northern edge is well-defined with sharp slope while the slope of the southern edge is more gentle with depth increasing slightly from the spine - i.e. middle - of the shoal toward the south, making the definition of the southern edge difficult to discern.

135 Field sampling

Samples were collected during three cruises in 2006 using the Louisiana Universities Marine Consortium (LUMCON) Research Vessel “ACADIANA”: May ( $21^{\text {st }}$ to $24^{\text {th }}$; Spring), August $\left(19^{\text {th }}\right.$ to $21^{\text {st }}$; Summer) and October the $30^{\text {th }}$ and November the $1^{\text {st }}$ (Autumn). Because of inclement weather, only 16 stations were sampled in October. Macrofauna was collected using a GOMEX box corer which has been shown to efficiently sample muddy and very fine to fine sandy sediments (Boland and Rowe 1991). Three replicates of $900 \mathrm{~cm}^{2}(30 \times 30 \mathrm{~cm})$ were taken at each station, for each of the three cruises. Subsamples for sediment analysis and chlorophyll $a$ sediment content were extracted from each box core with a $3 \mathrm{~cm}$ diameter cylinder over ca. $5 \mathrm{~cm}$ depth. Sediment samples were frozen until ready for analysis. Water characteristics (temperature, salinity, dissolved oxygen = DO) were monitored ca. $1 \mathrm{~m}$ above the bottom. 
Box core samples were sieved at sea on a $500 \mu \mathrm{m}$ sieve using seawater. Retained organisms, including sediment, was fixed and preserved in 5\% buffered formalin and returned to the laboratory.

\section{Laboratory analysis}

In the laboratory, macroinvertebrates were sorted to major taxon (i.e. polychaetes, 155 mollusks and others) and transferred to $70 \%$ ethanol. Bivalve and gastropod shells were examined for the presence of tissue. Wet weight of each group (shells included for mollusks and crustaceans) was taken before all individuals were sorted, identified to the species level (or the lowest practical taxonomic level) and enumerated. Species were classified into five feeding-guilds: (1) suspension-feeders, (2) surface deposit-feeders, (3) interface feeders (i.e. 160 species which can switch from suspension-feeding to surface deposit-feeding), (4) sub-surface deposit-feeders, (5) predators or scavengers/detritivores, based on taxonomic affiliation of families after Fauchald and Jumars (1979) for polychaetes, Yonge and Thompson (1976) for mollusks, Lecroy (2000) for amphipod crustaceans and Pechenik (2005) for other taxonomic groups. Some nematodes and planktonic copepods were retained but were excluded from analysis following Rzeznik-Orignac et al. (2004).

Sediment particle size analysis was conducted for each station. Sediment samples were washed with distilled water through a $63 \mu \mathrm{m}$ sieve to separate sand from silt and clay and to dissolve $\mathrm{NaCl}$ particles that may agglomerate smaller particles. The fraction $<63 \mu \mathrm{m}$ was collected in a bowl with water and allowed to settle for 72 hours. The water was then 170 siphoned and the silt/clay fraction dried to constant weight in an oven at $60^{\circ} \mathrm{C}$, then weighed. The sand fraction was dried to constant weight in an oven at $60^{\circ} \mathrm{C}$, and placed on a Ro-Tap sieve shaker for $3 \mathrm{~min}$ ( 21 sieves from $2 \mathrm{~mm}$ to $63 \mu \mathrm{m}$ mesh size with $1 / 2 \Phi$ intervals). The 
fraction retained on a $2 \mathrm{~mm}$ mesh size is the gravel fraction (consisting mostly of shell debris). The average particle size and the sorting index $\sigma$ were determined using the Folk and Ward (1957) method. Results were processed by the Gradistat software (Blott and Pye 2001).

\section{Statistical analysis}

Data were analyzed using univariate and multivariate methods. Macrofauna species 80 diversity was estimated using species richness and Hill's (1973) heterogeneity of diversity indices: N1 $=\exp \left(\mathrm{H}^{\prime}\right)$, where $\mathrm{H}^{\prime}$ is Shannon-Wiener diversity $\left(\log _{\mathrm{e}}-\right.$ Shannon 1948$)$; and N2 $=1 /$ SI, where SI is Simpson's index (Simpson 1949); N1 is sensitive to the number of medium-density species whereas N2 is sensitive to the number of very abundant species (Whittaker 1972). Species richness - i.e. the number of different species - is also called N0, 185 consistently with N1 and N2 indices. These indices are well suited to the analysis of diversity of benthic macrofauna communities and, together with the equitability index J' (Sheldon 1969), are recommended by Gray (2000) to measure heterogeneity of marine coastal diversity.

One-way ANOVA was used to test for geographic and seasonal trends in species 190 richness, diversity indices, and species abundances. Cochran's test was used to determine homogeneity of variances and, if necessary, data were $\log _{\mathrm{e}}(\mathrm{x}+1)$ transformed. When parametric ANOVA testing was acceptable, the Student-Newman-Keuls (SNK) test was used for multiple comparisons. As recommended by Hsu (1996), post-hoc comparisons were performed using Tukey HSD tests. A significance level of $p<0.05$ was used in all tests.

Differences in the composition of the macrofaunal assemblages between sites were determined using non-metric multidimentional scaling (nMDS) and cluster analysis (group average mode), followed methods of Clarke and Warwick (1994), using the Primer package 
(Clarke and Gorley 2001). Unstandardized multivariate data were $\log _{\mathrm{e}}(1+\mathrm{x})$ transformed to downweigh the importance of the very abundant species, and similarity matrices were calculated with the Bray-Curtis similarity index. The statistical significance of differences among sites was assessed using analysis of similarities (ANOSIM), a non-metric method based on randomization of rank-similarities among all samples and multiple pair-wise comparisons (Clarke 1993). To build the matrix, species occurring in less than 5\% of the samples, and with only one individual, were excluded. To identify within two different sample groups which species primarily accounted for the observed assemblage differences, SIMPER (similarity percentage) routines were performed using a decomposition of BrayCurtis dissimilarity on $\log _{\mathrm{e}}(\mathrm{x}+1)$ transformed abundance data. Species were listed in decreasing order of their importance in discriminating the two sets of samples (Clarke and Gorley 2001).

Two approaches were use to link environmental parameters - i.e. depth (m), sediment grain size (mean grain-size, sorting index), silt/clay and gravel (\%) content, bottom DO (mg $\left.\mathrm{L}^{-1}\right)$ and chlorophyll $a\left(\mathrm{mg} \mathrm{Chl} a \mathrm{~g}\right.$ sediment $\left.{ }^{-1}\right)$ sediment content - with the Ship Shoal macrobenthic community: (1) pair-wise regressions were used between environmental parameters and descriptors of benthic community (i.e. N0, N1, N2, taxonomic biomass or 215 mean species abundances) to explore if the variation in one environmental parameter followed the variation in species richness and (2) multivariate BIOENV procedures (see Clarke and Ainsworth 1993 for details) were used to determine how spatial patterns in multivariate invertebrate community structure were related to spatial patterns in multivariate environmental structure, i.e. to what extent observed biological patterns fit with variations in 220 environmental parameters. 


\section{Results}

\section{General description}

A total of 29331 macrofaunal individuals in 161 species were collected from Ship Shoal during the three cruises (see Appendix A). Polychaetes represented 45\% ( 72 species) of the total species number, following by crustaceans (28\%, 46 species) and mollusks $(17 \%$, 27 species). Other taxa (nemerteans, sipunculids, anthozoans etc.) represented 10\% (16 species). Global species richness exhibited a sharp decrease from spring to autumn, together with the mean species richness $\left(\mathrm{p}<10^{-5}\right)$. Except for a significant difference between N1 in autumn and N1 in spring or summer $(\mathrm{p}<0.003)$, heterogeneity indices and equitability did not exhibit seasonal variation (Table 1). In terms of abundances, polychaetes and crustaceans 235 predominated the Ship Shoal community with mean abundances between 1500 and 2000 individuals $\mathrm{m}^{-2}$ in spring (Figure 2). Within these two taxonomic groups, spionids and amphipods were respectively the largest component, representing more than $50 \%$ of individual polychaetes and $80 \%$ of the crustaceans. Amphioxus Branchistoma floridae (Cephalochordata) abundance peaked in summer. Community mean biomass (wet weight) 240 followed the same pattern, from $40.55 \mathrm{~g} \mathrm{~m}^{-2}(\mathrm{SE}=5.22)$ in spring to $21.77 \mathrm{~g} \mathrm{~m}^{-2}(\mathrm{SE}=2.88)$ in summer and $15.44 \mathrm{~g} \mathrm{~m}^{-2}(\mathrm{SE}=3.22)$ in autumn (Figure 3). While this decrease in biomass occurred throughout the year for polychaetes, it was not significant between summer and autumn for mollusks or between spring and summer for other taxa.

In terms of the measured environmental parameters, Ship Shoal constituted a relatively 245 homogenous sandy habitat (Table 3). Sediment analysis revealed that the sediment in all 21 stations was well or very well sorted and unimodal. Sediment is classified as sand or slightly gravelly sand for the most eastern stations (stations 14 to 18). Silt/clay (i.e. particles $<63$ 
$\mu \mathrm{m})$ and gravel (i.e. particles $>2 \mathrm{~mm}$ - primarily shell fragments) were very low at each station. Mean grain size, smaller in the western part of the shoal and larger in the eastern, was significantly inversely correlated in spring with N0 $(r=0.722 ; p<0.001)$, N1 $(r=0.477 ; p<$ $0.05)$, N2 $(r=0.421 ; \mathrm{p}<0.05)$ and species abundances $(\mathrm{r}=0.601 ; \mathrm{p}<0.01)$. The DO at the sediment surface was also correlated with N0 $(r=0.596 ; \mathrm{p}<0.01)$ and species abundances $(\mathrm{r}$ $=0.670 ; \mathrm{p}<0.01)$ in spring. Dissolved oxygen and sediment grain size were autocorrelated $(\mathrm{r}$ $=0.569 ; \mathrm{p}<0.01)$. No significant relation was found between environmental parameters and any diversity indices in summer or autumn.

Significant differences in diversity and abundances between western, middle and eastern stations of Ship Shoal, as well as between northern and southern stations (ANOVA; Table 2) were observed. More precisely, species richness was significantly higher in the southernmost stations of the shoal in spring $(p=0.032)$, summer $(p=0.002)$ and autumn $(p=$ 0.030) than in the middle or in the northernmost stations. Spring variations in global SR (i.e. total number of species for one station) and mean SR within the three transects across the shoal showed that both global and mean SR were higher at the southernmost stations (i.e. 17, 26 and 21) (Figure 4). The same pattern was indicated in summer and autumn. Mean species abundances were significantly higher in the southern edge in spring $(p=0.018)$, summer $(p<$ $\left.10^{-6}\right)$ and autumn $\left(\mathrm{p}<1.1610^{-4}\right)$ but were also significantly higher in the western region in spring $(\mathrm{p}=0.004)$, summer $\left(\mathrm{p}<10^{-6}\right)$ and autumn $\left(\mathrm{p}=1.1310^{-4}\right)$ than in the central or in the eastern region of the shoal. N1 and N2 indices exhibited more seasonal differences; in spring, both indices were significantly higher toward the west $\left(\mathrm{N} 1, \mathrm{p}=7.210^{-5} ; \mathrm{N} 2, \mathrm{p}=4.010^{-4}\right)$ and the southern edge $(\mathrm{N} 1, \mathrm{p}=0.012 ; \mathrm{N} 2, \mathrm{p}=0.029)$ but both indices only exhibited a significant 270 north-south gradient in summer $\left(\mathrm{N} 1, \mathrm{p}=610^{-4} ; \mathrm{N} 2, \mathrm{p}=4.410^{-6}\right)$ and no significant variation in autumn. While total biomass showed no significant variation, polychaete biomass was 
significantly higher in the west and south in spring $\left(\mathrm{p}=0.013\right.$ and $\mathrm{p}<10^{-7}$, respectively) and

\section{Macrofaunal benthic assemblages}

Annual variability

Cluster analysis of the macrofauna abundance data showed a strong seasonal effect in 280 sample composition (Figure 5), supported by ANOSIM (global R $=0.684 ; \mathrm{p}<0.001$; Table 4). SIMPER results (Table 4) comparing seasons showed that a small number of species contributed most to the dissimilarity among seasons: the amphipods Acanthohaustorius sp.A and Protohaustorius bousfieldi, the polychaetes Spiophanes bombyx and Dispio uncinata, and the amphioxus Branchiostoma floridae. These species had a very high frequency of

285 occurrence in samples each season but exhibited strong decreases in abundances, especially between spring and summer, with the exception of the amphioxus $B$. floridae which was more abundant in summer. Many species contributed to a smaller extent to the discrimination between spring and other seasons because they had low abundances and high frequency of occurrence in spring but occurred only in a few stations in summer and autumn. This was mainly the case for polychaetes such as Scolelepis texana, S. squamata, Paraprionospio pinnata, Spiochaetopterus costarum, Phyllodoce mucosa. In addition to B. floridae, a few species with a high frequency of occurrence were more abundant in summer, such as the polychaetes Thalenessa spinosa and Eupolymnia nebulosa or the nemertean Micrura leidyi. The polychaete Paramphimone sp.B and the shrimp Acetes americanus occurred almost exclusively in autumn. A few species, the polychaetes Neanthes micromma and Nepthys simoni, the gastropod Oliva sayana, the hermit crab Pagurus annulipes and the mole crab 
Albunea paretii, did not vary through the spring, summer or autumn with a high frequency of occurrence throughout.

Spatial distribution in spring, summer and autumn

Cluster analyses also showed a clear difference in species assemblages among samples from the same season (Figure 6). SIMPER analyses revealed that in spring (global $\mathrm{R}=0.564$; $\mathrm{p}<0.001$ ) and summer (global $\mathrm{R}=0.323 ; \mathrm{p}<0.001$ ), samples from eastern, middle and 305 western regions differed from each other mainly because of changes in species abundances. SIMPER also showed that discrepancies in species composition were predominately found between the eastern and the rest of the shoal, as the middle and western regions were similar in species composition. The MDS stress around 0.2 gives a useful 2-dimensional picture but an increase in MDS stress from 0.16 to 0.23 between spring and autumn is mainly due to the 310 replicates without amphioxus Branchiostoma floridae that contributed for the largest part to the similarity between each station for summer and autumn.

In spring, the amphipod Acanthohautorius sp.A and spionids Spiophanes bombyx and Dispio uncinata contributed most to the dissimilarity among regions but also most to the similarity within each region. Amphipod species contributed the most to changes in species 315 composition across the whole of the study area: Protohaustorius bousfieldi occurred almost only in western stations, while Hartmanodes ranyei, Microprotopus ranyei and Ampelisca sp.C were more abundant in the middle and western stations.

In summer, the amphioxus Branchiostoma floridae, the amphipod Acanthohautorius sp.A and the polychaete Prionospio (Apoprionospio) pygmaea contributed most to the dissimilarity between regions but also most to the similarity within each region. Polychaete species contributed most to the discrimination between groups: Euplolymnia nebulosa, 
Scoloplos sp.B, Tharyx annulosus dominated abundances in the western stations, Thalenessa

spinosa was more abundant in the middle region and Nereis falsa, Neanthes micromma and Travisia hobsonae in the eastern region.

In autumn, similarity indices decreased, as displayed by the greater scatter in the MDS plots of stations (Figure 6). This is due to larger discrepancies between species composition of the samples between and within individual stations. As in summer, the amphioxus $B$. floridae and the amphipod Acanthohautorius sp.A were the two structuring species. Also, $P$. bousfieldi occurred mostly in the western stations, and the polychaetes Magelona sp.A and Magelona sp.H occurred mostly in the northern and in the southern stations, respectively.

Though east-west changes were found, a high similarity threshold was also found between all northern and all southern stations from the three transects $(46.33 \%, 36.77 \%$ and $29.84 \%, 34.14 \%$ for spring and summer respectively, Figure 6 ). While this result was supported by diversity indices, this was also due to species that exhibited higher abundances

335 in the southern stations, such as the polychaetes Owenia fusiformis, Mediomastus californiensis, Tharyx annulosus, Magelona sp.H, Spiophanes bombyx, Scoloplos sp.B., Paraprionospio pinnata or higher abundances in the northern stations such as the polychaetes Nepthys simoni and Magelona sp.A or the cumaceans Oxyurostylis smithi and Cyclaspis varians.

BIOENV procedures showed that variations in macrobenthic assemblages were best matched by a combination of three or four environmental variables in spring, that were depth / grain size $/ \%$ gravel $($ Spearman correlation $=0.687)$ or depth $/$ grain size $/ \%$ gravel $/$ DO (Spearman correlation $=0.682)$. In summer, depth provided the best match $($ Spearman correlation $=0.505)$. No significant correlations were found in autumn.

\subsection{Feeding guilds}


Species that are able to switch between suspension-feeding and surface depositfeeding dominated the trophic guild in spring (47\%), and exhibited a decrease in summer (31\%) and autumn (30\%) (Figure 7). True suspension-feeders almost disappeared in autumn while the dominance of species relying on deposit-feeding varied but did not decrease. Only the dominance of predators/scavengers increased with seasons, from $8 \%$ in spring to $30 \%$ in autumn. In spring, abundance in sub-surface deposit-feeders were positively correlated with water depth $(\mathrm{r}=0.545 ; \mathrm{p}<0.01)$ and $\%$ silt/clay $(\mathrm{r}=0.524 ; \mathrm{p}<0.01)$ but negatively

355 correlated with sediment mean grain size $(r=0.471 ; \mathrm{p}<0.05)$. On the contrary, abundance of surface deposit-feeders was negatively correlated with water depth $(r=0.747 ; p<0.001)$ and $\%$ silt/clay $(r=0.538 ; p<0.01)$. In summer, abundance in sub-surface deposit-feeders was positively correlated with water depth $(r=0.451 ; \mathrm{p}<0.05)$ and abundance in surface depositfeeders was negatively correlated with depth $(r=0.427 ; p<0.05)$. Abundance in suspensionfeeders or interface-feeders was positively correlated with chlorophyll $a$ sediment content ( $\mathrm{r}=$ $0.523 ; \mathrm{p}<0.05)$

\section{Discussion}

Sandbanks and sandy shoals occur on continental shelves, in coastal embayments and in estuaries throughout the world. Their associated mineral deposits represent potentially valuable resources to help mitigate coastal erosion and to supply the raw material for beach reinforcement and coastal stabilization projects (Michel et al. 2001). Demands on coastalocean sand supplies are likely to increase as both human occupation of the coastal zone and sea level continues to rise, and as land-based sand-supplies decline. Although a large number 
of studies have examined sandbank formation, modeled sediment transport, and evaluated the importance of shoals to local hydrodynamic conditions (e.g. Berthot and Pattiaratchi 2004), few ecological studies have examined the functional value of these high-relief structures in their ecosystems, especially in terms of biodiversity and associated ecological services. Even so there is a growing awareness of the potential impact of sand and gravel mining, to both the extracted and receiving sites, in coastal-ocean systems (i.e. Defeo et al. 2009; Peckenham et al. 2009; Pempel and Church 2009; Zeppelini et al. 2009), and more studies are needed to aid policy decisions. Finally, lessons learned from careful studies of the impacts of current coastal-ocean sand mining operations could prove valuable as extractions of other marine minerals begin and increase (e.g. Rona 2008).

\section{The Ship Shoal macrobenthic assemblage}

Ship Shoal is a large, discrete formation composed of fine to very fine sand (ca. 150 $\mu \mathrm{m}$ diameter) about $25 \mathrm{~km}$ offshore from the Louisiana coast. Environmental gradients of water depth (increasing depth toward the east) and granulometry (increasing mean grain size toward the east) characterize the Shoal. In terms of benthic macroinvertebrates, our results suggest that Ship Shoal represents a faunally distinct habitat type in a transition between in-

390 shore and off-shore habitats. Species composition revealed differences between east and west areas, along with differences between northern and southern edges of the shoal. Ship Shoal hosted a unique combination of macroinfauna composed of species commonly found typically in the swash zone of sandy beach communities associated with the Mississippi and northwest Florida seashore (e.g. Leitoscoloplos fragilis, Scolelepis squamata, Dispio uncinata) (Rakocinski et al. 1998), or abundant in shallow enclosed bays of the northern Gulf of Mexico (e.g. Paraprionospio pinnata, Gyptis vittata, Notomastus latericeus, Mulinia lateralis) 
(Mannino and Montagna 1997; Montagna and Ritter 2006), as well as species typically found

in muddy off-shore environments south of Terrebonne Bay, Louisiana (e.g. Armandia maculata, Magelona sp.H, Tellina versicolor, Nassarius acutus) (Baustian et al 2009). More generally, shoals exhibit a unique physical regime, leading to special hydrodynamic and sedimentary patterns and to distinct species assemblages. But the extent to which associated fauna is distinct from surrounding environments is poorly known (Kaiser et al. 2004).

A significant number of species not reported previously for the Louisiana continental shelf were found on Ship Shoal. Uebelacker and Johnson (1984) provided a distribution 405 range of polychaete species occurring on a large portion of the outer continental shelf of the northern Gulf of Mexico, e.g. south Texas (Texas), central Louisiana (Louisiana) and Mississippi-Alabama-west Florida (Florida) outer shelves. Based on that comprehensive work, we report that $50 \%$ of the polychaete species found on Ship Shoal (35 species) were recorded either from the Florida continental shelf only (23 species) or from both the Texas 410 and Florida continental shelves (12 species). Thus half of the Ship Shoal polychaete species had not been recorded for the Louisiana continental shelf. While most of these polychaete species had a low density and widely scattered distribution on Ship Shoal (e.g. Streptosyllis pettiboneae, Myriowenia sp.A, Anaitides groenlandica), a few species (Phyllodoce mucosa, Thalenessa spinosa, Nereis falsa or Nepthys simoni) exhibited high frequency of occurrence 415 with low density (ca. 10 individual $\mathrm{m}^{-2}$ ).

The Ship Shoal community appears to be a melange of species. Among species found throughout the year, with a high frequency of occurrence, mole crabs Albunea paretii and amphioxus Branchiostoma floridae best typified the very fine-sand shoal community and comprised most of the biomass. In this Albunea-Brachiostoma community, defined based on 420 the two ubiquitous species which constitute the majority of the biomass on the shoal, we typically found the polychaetes Nephtys simoni, Neanthes micromma, Dispio uncinata and 
Magelona sp.A, the amphipod Acanthohautorius sp.A and the burrowing shrimp Ogyrides

alphaerostris. They constituted the basis of the sandy shoal community, which exhibited variation according to seasons or according to on-shore or off-shore influences. As expected, the shoal community is typified by species that are adapted to changes in hydrography and are able to re-burrow rapidly when washed out of the sediment during a storm event. Moreover, Nephtyid or Magelonid polychaetes distinguish the fauna of sandbanks in the North-Sea (Vanosmael et al., 1982).

The occurrence of amphioxus (Branchiostoma floridae) has been reported in sandy430 shore macrobenthic community of barrier islands to the west of the Mississippi river (Hefley and Shoemaker 1952; Rakocinski et al. 1998), but this is the first report of high abundances of

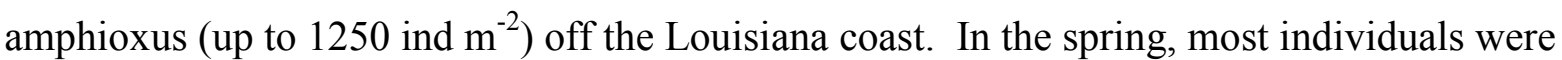
large ovigerous females. In the summer, many juveniles were present, suggesting Ship Shoal is a locally important habitat for reproduction and early summer recruitment. The findings 435 presented here strongly suggest that Ship Shoal in particular and Louisiana sandy shoals in general play an important role in the marine landscape ecology of the northern Gulf of Mexico, by aiding dispersal and gene flow of benthic species over large spatial scales. The sediment characteristics of Ship Shoal are similar to that of the Florida shelf (Posey et al. 1998). In addition, a recent large-scale study of current circulation in the northern Gulf of Mexico (Ohlmann and Niiler 2005) found a strong inter-regional connectivity, especially during passage of tropical storms that allowed particles to cross the Florida-Louisiana shelfbreak and the Mississippi river outflow. Thus, Ship Shoal represents a suitable area along the Louisiana coast for larvae to settle and for a diverse group of species adapted to life in fine sand to survive and develop.

More locally, Ship Shoal may serve as a source pool for recruitment of benthic invertebrate larvae and adults to surrounding areas affected by seasonal hypoxia. Powilleit 
and Kube (1999) found rapid recolonization by adult benthic macrofauna from an undisturbed

shallow coastal area with high macrofauna density to an area moderately affected by hypoxia in the Pomeranian Bay in the Southern Baltic Sea. Ship Shoal may provide the same function 450 as abundances of benthic invertebrates on the hypoxia affected areas of the Louisiana shelf increase after hypoxia ends (Rabalais et al., 2001). In addition, a study designed to study hyperbenthic (=suprabenthic) species assemblages of subtidal sandbanks in the North Sea, Dewicke et al. (2003) hypothesized that sandbanks might also sustain nursery areas for several fish and crustacean species. Molecular tools would be of primary interest in testing 455 hypotheses regarding gene flow and dispersal.

\section{Is Ship Shoal a diversity hotspot?}

Few authors have focused specifically on sandbanks, employing multiple collections with quantitative sampling devices (Kaiser et al. 2004). In the present study, the overall species richness of macrobenthos on Ship Shoal totaled 118 species (with a mean per sample of $23.71 \pm 1.05)$. Benthic assemblages over a large sampling area off the central coast of Louisiana surrounding Ship Shoal showed that the mean species richness for summer was $46519.1 \pm 2.3$ (Baustian et al. 2009). This investigation covered a much broader area (ca. 4000 $\mathrm{km}^{2}$ ) than the present study (ca. $200 \mathrm{~km}^{2}$ ) and encountered a greater habitat variety (muddy substrata through gravelly soft-bottoms). One would thus expect the off-shoal species richness to be comparatively much higher than Ship Shoal for a similar number of stations (Rosenzweig 1995). A comparable study was conducted on the Kwinte Bank in the Belgian

470 coastal waters on the area where the sediment is composed of coarse to fine grained sand (Vanosmael et al. 1982). The Kwinte Bank was found to be more specious than the 
surrounding habitat composed of finer grained sediment and considered a "biogeographical

In addition, Baustian (2005) studied seasonal variation in macrobenthic community at one particular site that typifies muddy soft-bottom environments surrounding Ship Shoal (ca. $10 \mathrm{~km}$ off Ship Shoal). This seasonal survey provides a relevant comparison of seasonal patterns with the present study. It showed a similar decrease in species richness and abundances from spring to autumn: mean SR ranged from 14 to 4 species between May and October, while the range was 33 to 13 species for the same months in Ship Shoal sediments.

480 Thus, Ship Shoal appears to maintain a higher number of species than nearby locations on the Louisiana shelf. Biodiversity in benthic communities is often linked with many environmental factors, of which sediment characteristic is of primary importance (Gray 1974). Traditionally, infaunal species richness is lower in muddy communities than in sandy community but heterogeneous sands have typically more species than well-sorted mobile sands, which are characterized by dominance of polychaetes and amphipods (e.g. Van Hoey et al. 2004), as found in Ship Shoal.

Significant variation in species diversity occurred over a small latitudinal gradient (less than $10 \mathrm{~km}$ ) between the northern and southern edges of Ship Shoal (biodiversity in southern stations was higher). This north-south gradient is characterized by the higher abundances of large tube-building polychaete species at stations close to the southern edge in deepening water. For example, average abundances for the main tube-building species Onuphidae Diopatra cuprea and Onuphis eremita occulata and Oweniidae Owenia fusiformis were $6.17 \pm 6.17,74.03 \pm 20.38$ and $513.67 \pm 482.31$ individuals $\mathrm{m}^{-2}$ for the southern edge, versus $0,4.90 \pm 3.23$ and $54.33 \pm 54.33$ individuals $\mathrm{m}^{-2}$ for the northern edge, respectively.

495 These tube-builders contribute to the high diversity on Ship Shoal compared to nearby nonshoal habitats. Tubes that protrude several $\mathrm{cm}$ above the sediment surface are known to 
increase surface heterogeneity and provide habitat for other small invertebrates (Zühlke 2001;

Dubois et al 2002), as well as settlement surface for larval and postlarval benthic organisms (Qian and Chia 1991). This last hypothesis was supported by high densities of spionid and oweniid juveniles in southern samples (e.g. up to $1478 \pm 475$ juveniles $\mathrm{m}^{-2}$ of $O$. fusiformis in the station 21, Fig. 1).

Baustian's (2005) seasonal study off Ship Shoal showed that, while polychaetes dominated (ca. 50\%) throughout the year, mollusks were the second most important taxonomic group (24\% in May, $45 \%$ in August and 38\% in October). Nuculana acuta, Natica pusilla and Abra aequalis were particularly abundant in Baustian's study but were found on Ship Shoal in very low abundances (less than 3 ind. $\mathrm{m}^{-2}$ ). We found that mollusks represented $<3 \%$ of the macroinfauna on Ship Shoal, but that crustaceans, and especially amphipods, were almost as abundant as polychaetes (even more abundant in spring), while it is traditionally assumed that polychaetes are the most diverse and dominant taxonomic group in most marine and estuarine environments (e.g. Hutchings 1998).

\section{Is Ship Shoal a local refuge from seasonal hypoxia?}

Ship Shoal is situated within one of the largest hypoxic areas in the world (Rabalais et 515 al. 2001). Mid-summer surveys from 1993 to 2000 revealed severe and persistent hypoxia (i.e. DO $<2 \mathrm{mg} \mathrm{L}^{-1}$ ) on the inner- to mid-Louisiana continental shelf (Rabalais et al. 2001). Yet, our estimates of bottom DO concentrations over the entire shoal were fairly high and constant in spring $\left(6.1 \pm 1.5 \mathrm{mg} \mathrm{L}^{-1}\right)$, summer $\left(6.3 \pm 1.1 \mathrm{mg} \mathrm{L}^{-1}\right)$ and autumn $\left(6.9 \pm 0.3 \mathrm{mg} \mathrm{L}^{-}\right.$ ${ }^{1}$ ), with only one spring sample reaching $2.0 \mathrm{mg} \mathrm{L}^{-1}$. Amphipods occurred in very high 520 abundance and diversity over Ship Shoal, with a total of 20 species identified. Acanthohaustorius sp.A, Protohaustorius bousfieldi, Ampelisca sp.C and Hartmanodes nyei 
were highly-ranked among the benthic assemblages throughout the year. In contrast,

complete and long lasting (one or more years) disappearance of amphipod communities was recorded at stations in an area of severe oxygen depletion in the Pomeranian Bay of the Southern Baltic Sea (Powilleit and Kube 1999). More locally, Baustian (2005) confirmed that crustaceans in general and amphipods in particular are absent from muddy areas surrounding Ship Shoal in summer and autumn. As amphipods are known to be affected by low oxygen (Gaston 1985; Wu and Or 2005), together these results support the hypothesis that Ship Shoal is a hypoxia refuge for benthic species.

Irregular bottom topography in shallow waters such as sand banks and shoals has been known to influence coastal hydrodynamics and bottom boundary layer dynamics (Pepper and Stone 2004). For instance, such bathymetric elevated areas act as submerged breakwaters, mitigating wave energy, flow patterns, and consequently increase DO concentrations (e.g. Kobashi et al. 2007) and the shoal is too shallow to facilitate local stratification (Grippo et al., 2009). Moreover, biogenic activity exemplified by the high density of tubiculous polychaetes (e.g. spionids, representing between $30 \%$ and $50 \%$ of polychaete density, as well as Owenia fusiformis, or Onuphis eremita occulata) may enhance oxygen flux in sediment surface layer (Jorgensen et al. 2005). Together, these factors may contribute to Ship Shoals high DO concentrations.

Species abundances exhibited a steady but large rate of decline between spring, summer and autumn, affecting amphipods as well as all other taxonomic groups (except amphioxus). The magnitude and extent of these declines suggest an increase in the rate of mortality that is most likely not due to a short life-span. The most abundant structuring amphipod species - Acanthohaustorius sp. - exhibit a lifespan of 1.5 years (Sainte-Marie 1991) and the most abundant polychaete family - spionids - exhibit a mean life-span of 1.8 years (McHugh and Fong 2002). As indicated by our DO measurements (ca. $6 \mathrm{mg} \mathrm{L}^{-1}$ ), a 
hypoxia event is not likely the cause for such a decrease in species abundances on Ship Shoal.

Sedimentation in the form of an ephemeral fluiditic flood layer has been reported to have a dramatic effect on benthic species abundances on the US Pacific Northwest coast (e.g. Wheatcroft 2005). However, a 2006 survey done by US Army Corps of Engineers (data available at www.mvn.usace.army.mil/eng/edhd/watercon) did not reveal summer and/or autumn flooding of the Atchafalaya and Mississippi Rivers on the adjacent Louisiana continental shelf that could lead to a large-scale mud-layer deposition. Furthermore, our sediment analyses over the entire Ship Shoal area found that silt and clay was always $<2 \%$ of 555 the total sediment. Flooding events are most likely to affect Ship Shoal in the winter and spring when continental cold fronts occur and when river flow is high (Allison et al 2005). Recent modeling investigations showed that ephemeral and patchy fluiditic mud may occur in spring on Ship Shoal (Kobashi et al. 2007). While we did not find evidence of this in our seasonal survey, it may have had adversely affected the benthic populations on a small-scale.

560 Lastly, a seasonal influx of benthic predators may strongly affect benthic populations (e.g. Langlois et al 2006). Gelpi et al. (in review) found expectedly high concentrations of spawning/hatching blue crabs Callinectes sapidus in summer 2006 in Ship Shoal, but not in spring trawls. Stable isotopes and gut content data (Gelpi et al., in prep.) showed that these blue crabs actively fed on Ship Shoal. C. sapidus is known to be an important benthic 565 predator which may have a strong influence on polychaete and bivalve populations (Bell et al. 2003). We suggest here that seasonal blue crab predation (perhaps supplemented by other predators such as white, brown shrimp and croaker) on Ship Shoal may contribute to the observed seasonal decline in the macroinfaunal community.

$570 \quad$ Is Ship Shoal macrofauna sensitive to sand-mining disturbance? 
Ship Shoal has been identified as perhaps the most significant sand resource (ca. 1.6

billion cubic yards of fine sand) in the northern Gulf of Mexico (Brooks et al. 1999).

Dredged sand may be used to supply beach reinforcement and coastal stabilization projects and mitigate Louisiana coastal erosion and wetland loss (Michel et al. 2001). Much previous research suggests that dredging and mining activities negatively affect, at least temporarily, shoal benthic communities (Newell et al. 1998). Our study provides baseline information to better understand the ecological services provided by Ship Shoal and to predict its sensitivity to human disturbances in general and sand-mining disturbances in particular. Given the size of Ship Shoal, it is likely that mining would remove only a fraction of the available sand but localized effects may be strong and similar to responses experienced by sandbanks worldwide.

Newell et al. (1998) estimated that the rate of recovery for sandy environments after sediment extraction is much longer ( 2 to 3 years) than the rate for muddy environments (6 to 5858 months), and may be even longer depending on the amount of sand removed, the proportion of slow-growing species and the intensity of environmental disturbance. Palmer et al. (2008) found that macrofauna off the western coast of Louisiana were not fully recovered three years after dredging a sand excavation pit. The macrofauna assemblage of Ship Shoal is speciesrich with strongly contrasting life history characteristics compared to the surrounding offshoal community (Palmer et al. 2008; Baustian et al 2009). Many of Ship Shoal's more abundant species (including Branchisotoma floridae, Scoloplos sp., Sabellides sp., Terebellides sp. and Dosinia sp., Tellina sp., Ensis sp.) have been designated "equilibrium species" (K-strategists) (Newell et al. 1998) because they are relatively large in body size, have a slow reproduction rate and a long life-cycle. These species, and the amphipod fauna as 595 a whole, are considered sensitive species (Geistera and Dauvin 2000), and are probably controlled by biological interactions rather than extreme changes in environmental conditions 
on Ship Shoal. Large species accounted for most of the biomass on Ship Shoal, which is high

(37.3 $\mathrm{g}$ wet weight $\mathrm{m}^{-2}$ ) compared to other areas of similar water depth (Pinn and Roberson 2003; Thouzeau et al. 1991). These observations suggest that Ship Shoal's macrofauna will

600 be strongly affected by and slow to recover from sand extraction. We predict that sand extraction on Ship Shoal and other sandbanks will cause a shift in dominance to small, rapidly-growing species including spionid polychaetes. These "disturbance specialists" or “opportunistic species" (r-selected species, Pianka 1970) are found throughout the world. They have a rapid rate of reproduction and body growth which facilitates colonization of 605 disturbed habitats (e.g. Dubois et al. 2002; Palmer et al. 2008), and are less sensitive to sandmining. The resulting reduction in macrofaunal biomass may elicit indirect effects at higher trophic levels, for example on fishes and crustaceans using Ship Shoal as a foraging ground.

Sand mining will also impact physical factors that have direct and indirect effects on ecological services. Variation in water depth and mean particle size was closely associated

610 with changes in benthic communities across Ship Shoal. Excavation of sand will lead to localized increases in water depth and turbidity (due to the overflow of fine particles). Even small changes in water depth may influence primary production on Ship Shoal. Grippo et al. (2009) found that benthic microalgae may have higher biomass than phytoplankton integrated through the water column on Ship Shoal, suggesting benthic primary production contributes 615 significantly to the shoal's food web. For example, the high macrofaunal biomass we observed may be attributed to high levels of in situ primary production (e.g., our observed correlation between chl $a$ and benthic interface feeders). Changes in primary production and a finer particle size will likely influence the benthic community by reducing community biomass and altering community composition. Higher trophic levels may be influenced by 620 resulting bottom-up effects induced by changes in the biomass or community composition of macrofauna. 


\section{Conclusion}

Sandy shoals appear to provide key ecological services at multiple trophic levels from all localities studied so far. For example, Vanaverbeke et al. (2007) showed that sand extraction affected the nematode community at the base of the food web from the Kwinte sandbank (Southern Bight of the North Sea). Kaiser et al. (2004) showed that sandbanks on the Welsh coastline (United Kingdom) hosted distinct fish assemblages 630 foraging on benthic species colonizing the sandbanks. McGuire and Winemiller (1998) demonstrated that the presence of sandbanks in the Cinaruco estuary (Venezuela) was associated with a greater frequency of dolphin sightings. Our work suggests that larvae spawned by benthic invertebrates living on Ship Shoal contribute to the recolonization of a nearby seasonally hypoxic "dead zone" and that this sandy habitat is a species richness

635 hotspot that hosts a unique macrobenthic community that contrasts strongly with the surrounding deeper muddy community. Ship Shoal offers a hypoxia refuge for benthic species, as well as a settlement area for postlarvae and juveniles, enhancing the survival probability for newly settled species. Ship Shoal might also be an important foraging ground for fishes or large crustaceans preying upon benthic invertebrates, especially when nearby severe hypoxia reduces essential habitat.

The effects of sand-mining on Ship Shoal benthos would likely last for months to years and effects may extend to shoal-dependent nekton by food web interactions. In general, human interventions to combat coastal erosion and shoreline retreat have been shown to cause local ecological impacts and a loss of biodiversity that may have cumulative large-scale

645 consequences (Schlacher et al. 2007). Because of the scale of this problem, the continued existence of sandy shoals - the main sand resource all over the world - as functional 
ecosystems is likely to depend on direct conservation efforts. Our work, although not a before-after study, suggests that shoals are more than mineral resources and that sand-mining activities should be carried out with caution, especially where sandy shoals differ markedly 650 from surrounding benthic habitats.

\section{Acknowledgements}

This study was jointly funded by the U.S. Department of Interior Minerals

655 Management Services (contract number 1435-01-04-CA-35162) and by the Louisiana Department of Natural Resources (contract number 2513-04-02/613082). We wish to thank the Drs. Nancy Rabelais, Darryl Felder, Sara Lecroy, Felix Jose and Richard Shaw; the crew of the Acadiana; and Mss Sara Arndt and Elaine D. Evers for their advise and assistance. 
Appendix A. Families and species identified from the GOMEX box core samples. Core

cross-sectional area $=0.09 \mathrm{~m}^{2}$. Mesh size $500 \mu \mathrm{m}$

\section{Plathelminthes}

Plehniidae

Probursa veneris

Cnidaria

Actinostolidae Discocelides ellipsoides

burrowing Anemone sp.2
burrowing Anemone sp.3

\section{Nemertea}

Lineidae

Micrura leidyi

Nemertea sp. 1

Nemertea sp.2

Nemertea sp.3

\section{Polychaeta}

Orbiniidae

Paraonidae

Leitoscoloplos fragilis

Scoloplos rubra

Scoloplos sp.B

Phylo felix

Cirrophorus forticirratus

Aricidea fragilis

Aricidea suecica

Aricidea alisdairi

Aricidea quadrilobata

Paraonis pygoenigmatica

Spionidae Spiophanes bombyx

Boccardiella sp.A

Polydora ligni

Polydora socialis

Dispio uncinata

Aonides paucibranchiata

Scolelepis texana

Scolelepis squamata

Paraprionospio pinnata

Prionospio cristata

Prionospio pygmaea

Prionospio cirrobranchiata

Spio pettiboneae

Microspio pigmentata

Magelonidae Magelona sp.A

Magelona sp.H

Poecilochaetidae Poecilochaetus johnsoni

Chaetopteridae Spiochaetopterus costarum

Mesochaetopterus capensis

Cirratulidae

Tharyx annulosus

Chaetozone sp.A

Cirriformia sp.B

Capitellidae Mediomastus californiensis

Mastobranchus sp.A

Notomastus latericeus

Arenicolidae

Opheliidae

Arenicola sp.

Phyllodocidae

Travisia hobsonae

Phyllodoce mucosa

Anaitides groenlandica

Polynoidae

Lepidonotus sublevis

Perolepis sp.A

Polynoidae sp

Eulepethidae Grubeulepis sp.A

Sigalionidae Thalenessa spinosa

Fimbriosthenelais minor

Hesionidae

Podarke sp.A

Gyptis brevipalpa

Pilargiidae

Sigambra tentaculata

Synelmis klatti

Syllidae

Nereidae

Streptosyllis pettiboneae

Neanthes micromma

Mreniella sp.C

Polychaeta (cont.)

\begin{tabular}{|c|c|}
\hline Goniadidae & Goniada littorea \\
\hline \multirow[t]{2}{*}{ Nephtyidae } & Nephtys simoni \\
\hline & Aglaophamus verrilli \\
\hline Amphinomidae & Paramphinome sp.B \\
\hline \multirow[t]{2}{*}{ Onuphidae } & Diopatra cuprea \\
\hline & Onuphis eremita oculata \\
\hline \multirow[t]{2}{*}{ Lumbrineridae } & Lumbrineris latreilli \\
\hline & Lumbrineris tenuis \\
\hline \multirow[t]{2}{*}{ Oweniidae } & Owenia fusiformis \\
\hline & Myriowenia sp.A \\
\hline \multirow[t]{2}{*}{ Ampharetidae } & Sabellides sp.A \\
\hline & Ampharete sp.A \\
\hline \multirow[t]{2}{*}{ Terebellidae } & Loimia viridis \\
\hline & Eupolymnia nebulosa \\
\hline bellidae & Chone americana \\
\hline
\end{tabular}

\section{Mollusca}

Olividae

Nereis falsa
Nassariidae

Fasciolariidae

Columbellidae

Naticidae

Litiopinae

Calyptraeidae

Cyclostremellinae

Tellinidae

Oliva sayana

Olivella mutica

Nassarius acutus

Latirus carinifer

Anachis obesa

Polinices duplicatus

Natica pusilla

Sinum maculatum

Epitonium multistriatum

Cyclostremella humilis

Strigilla pisiformis

Tellina iris

Tellina versicolor

Macoma pulleyi

Mactridae

Mulinia lateralis

Raeta plicatella

Cardiidae

Solecurtidae

Americardia media

Ungulinidae

Abra aequalis

Lucinidae

Diplodonta soror

Parvilucina multilineata

Veneridae

Linga amiantus

Solenoidea

Dosiniinae

Pandoridae

Chione clenchi

Solen viridis

Arcidae

\section{Crustacea}

Haustoriidae

Synopiidae

Liljeborgiidae

Isaeidae

Corophiidae

Ampelisca

Oedicerotidae

Ischyroceridae Ericthonius brasiliensis

Dosinia discus

Pandora trilineata

Anadara transversa

Acanthohaustorius sp. A

Protohaustorius bousfieldi

Pseudohaustorius americanus

Metatiron triocellatus

Metatiron tropakis

Listriella barnardi

Microprotopus raneyi

Monoconophium sp. A

Monocorophium tuberculatum

Ampelisca sp. C

Hartmanodes nyei

Americhelidium americanum

Cerapus tubularis

Argissidae Argissa hamatipes

Stenothoidae Parametopella cypris

Caprellidae Unknown species

Platyischnopidae Eudevenopus honduranus

Phoxocephalidae

Trichophoxus sp.

Portunidae
Crepidula plana
Crustacea (cont.)

$\begin{array}{ll}\text { Xanthidae } & \text { Xanthidae sp. } \\ \text { Majidae } & \text { Libinia dubia } \\ & \text { Mithrax acuticornis } \\ \text { Paguridae } & \text { Pagurus annulipes } \\ \text { Albuneidae } & \text { Albunea paretii } \\ & \text { Lepidopa benedicti } \\ \text { Porcellanidae } & \text { Euceramus praelongus } \\ - & \text { Thalassinidean sp. } \\ \text { Callianassidae } & \text { Glypturus nr. acanthochirus } \\ \text { Pasiphaeidae } & \text { Leptochela serratorbita } \\ \text { Processidae } & \text { Processa hemphilli } \\ \text { Hippolytidae } & \text { Latreutes parvulus } \\ \text { Panaeidae } & \text { Solenocera vioscai } \\ \text { Sergestidae } & \text { Lucifer faxoni } \\ & \text { Acetes americanus } \\ \text { Ogyrididae } & \text { Ogyrides alphaerostris } \\ \text { Nannosquillidae } & \text { Coronis scolopendra } \\ & \text { Squilla sp.A } \\ \text { Diastylidae } & \text { Oxyurostylis smithi } \\ \text { Bodotriidae } & \text { Cyclaspis varians }\end{array}$

Echinodermata

Amphiuridae Amphipholis squamata

Sipuncula

Golfingiidae Phascolion strombi

Golfingia tenuissima

Sipunculidae Sipunculus sp.

Echiura

Echiuridae Thalassema sp

Phoronida

Phoronidae Phoronis architecta

Chordata

Branchiostomatidae Branchiostoma floridae 


\section{References}

Allison MA, Sheremet A, Goni MA, Stone GW (2005) Storm layer deposition on the Mississippi-Atchafalaya subaqueous delta generated by Hurricane Lili in 2002. Cont Shelf Res 25:2213-2232

Berthot A, Pattiaratchi C (2004) Maintenance of headland-associated linear sandbanks: modelling the secondary flows and sediment transport. 12th International Biennial Conference on Physics of Estuaries and Coastal Seas. Springer Heidelberg, Merida, Mexico, pp526-540

Baustian MM (2005) Benthic communities in the northern Gulf of Mexico hypoxic area: potential prey for demersal fish. Master Thesis, Louisiana State University. http://etd.lsu.edu/docs/available/etd-07142005-082657

Baustian MM, Craig JK Rabalais NN (2009) Effects of summer 2003 hypoxia on macrobenthos and Atlantic croaker foraging selectivity in the northern Gulf of Mexico. J Exp Mar Biol Ecol in press

Bell GW, Eggleston DB, Wolcott TG (2003) Behavioral responses of free-ranging blue crabs to episodic hypoxia. II. Feeding. Mar Ecol Prog Ser 259:227-235

Blott SJ, Pye K (2001) GRADISTAT: a grain size distribution and statistics package for the analysis of unconsolidated sediments. Earth Surf Proc Land 26:1237-1248

Boland GS, Rowe GT (1991) Deep-Sea Benthic Sampling with the Gomex Box Corer. Limnol Oceanogr 36:1015-1020 
Brooks RA, Purdy CN, Bell SS, Sulak KJ (2006) The benthic community of the eastern US continental shelf: A literature synopsis of benthic faunal resources. Cont Shelf Res $26: 804-818$

Cheung MM, Brooks RA, Sulak KJ (2006) Benthic polychaete assemblages on Sabine and Heald sand banks, northern Gulf of Mexico: a pre-disturbance study on a sand extraction site, USGS Outer Continental Shelf Ecosystem Studies Program Report, Gainesville, FL

Clarke KR (1993) Nonparametric multivariate analyses of changes in community structure. Aust J Ecol 18:117-143

Clarke KR, Ainsworth M (1993) A method of linking multivariate community structure to environmental variables. Mar Ecol Prog Ser 92:205-219

Clarke KR, Gorley RN (2001) PRIMER v5 : User Manual/Tutorial. PRRIMER-E Ltd, Plymouth

Clarke KR, Warwick RM (1994) Change in marine communities: an approach to statistical analysis and interpretation. Report No. 144, Plymouth Marine Laboratory, Plymouth

Defeo O, McLachlan A, Schoeman DS, Schlacher TA, Dugan J, Jones A, Lastra M, Scapini F (2009) Threats to sandy beach ecosystems: A review. Est Coast Shelf Sci 81:1-12

Dewicke A, Cattrijsse A, Mees J, Vincx M (2003) Spatial patterns of the hyperbenthos of subtidal sandbanks in the southern North Sea. J Sea Res 49:27-45

Drucker BS, Waskes W, Byrnes MR (2004) The US minerals management service outer continental shelf sand and gravel program: Environmental studies to assess the potential effects of offshore dredging operations in federal waters. J Coast Res 20:1-5

Dubois S, Retiere C, Olivier F (2002) Biodiversity associated with Sabellaria alveolata (Polychaeta : Sabellariidae) reefs: effects of human disturbances. J Mar Biol Ass UK $82: 817-826$ 
Fauchald K, Jumars PA (1979) The diet of worms: A study of polychaete feeding guilds. Oceanogr Mar Biol Ann Rev 17:193-284

Folk RL, Ward WC (1957) Brazos River bar: a study in the significance of grain size parameters. J Sed Pet 27:3-26

715 Gaston GR (1985) Effects of Hypoxia on macrobenthos of the inner shelf off Cameron, Louisiana. Est Coast Shelf Sci 20:603-613

Gesteira JLG, Dauvin JC (2000) Amphipods are good bioindicators of the impact of oil spills on soft-bottom macrobenthic communities. Mar Poll Bull 40:1017-1027

Gray JS (1974) Animal-sediment relationships. Oceanogr Mar Biol 12:223-261

Gray JS (2000) The measurement of marine species diversity, with an application to the benthic fauna of the Norwegian continental shelf. J Exp Mar Biol Ecol 250:23-49

Grippo MA, Fleeger JW, Condrey RE, Carman KR (2009 High biomass of benthic microalgae found on Ship Shoal, north-central Gulf of Mexico. Bull Mar Sci 84:237256

Hefley HM, Shoemaker H (1952) The occurrence of Branchiostoma (Amphioxus) in Mississippi and Louisiana. Science 115:48

Hill MO (1973) Diversity and evenness: a unifying notation and its consequence. Ecology $54: 427-432$

Hutchings PA (1998) Biodiversity and functioning of polychaetes in benthic sediments. Biodiv Conserv 7:1133-1145

Jorgensen BB, Glud RN, Holby O (2005) Oxygen distribution and bioirrigation in Arctic fjord sediments (Svalbard, Barents Sea). Mar Ecol Prog Ser 292:85-95

Justic D, Rabalais NN, Turner RE (1996) Effects of climate change on hypoxia in coastal waters: A doubled $\mathrm{CO}_{2}$ scenario for the northern Gulf of Mexico. Limnol Oceanogr $735 \quad 41: 992-1003$ 
Kaiser MJ, Bergmann M, Hinz H, Galanidi M, Shucksmith R, Rees EIS, Darbyshire T, Ramsay K (2004) Demersal fish and epifauna associated with sandbank habitats. Est Coast Shelf Sci 60:445-456

Kobashi D, Jose F, Stone GW (2007) Impacts of fluvial fine sediments and winter storms on a transgressive shoal, off south-central Louisiana, U.S.A. Proceedings of the 9th International Coastal Symposium. J Coast Res, Gold Coast, Australia, p858-862

Langlois TJ, Anderson MJ, Babcock RC (2005) Reef-associated predators influence adjacent soft-sediment communities. Ecology 86:1508-1519

Lecroy S (2000) An illustrated identification guide to the nearshore marine and estuarine Gammaridean Amphipoda of Florida, vol 1. Families Gammaridae, Hadziidae, Isaeidae, Melitidae and Oedicerotidae. Tallahassee. Florida Department of Environmental Protection, Florida

Mannino A, Montagna PA (1997) Small-scale spatial variation of macrobenthic community structure. Estuaries 20:159-173

McGuire TL, Winemiller KO (1998) Occurrence patterns, habitat associations, and potential prey of the river dolphin, Inia geoffrensis, in the Cinaruco river, Venezuela. Biotropica $30: 625-638$

McHugh D, Fong PP (2002) Do life history traits account for diversity of polychaete annelids? Invert Biol 121:325-338

755 Michel J, Nairn R, Johnson JA, Hardin D (2001) Development and design of biological and physical monitoring protocols to evaluate the long-term impacts of offshore dredging operations on the marine environment, U.S. Department of the Interior, Mineral Management Service, International Activities and Marine Minerals Division (INTERMAR), Herndon, VA 
760 Montagna PA, Ritter C (2006) Direct and indirect effects of hypoxia on benthos in Corpus Christi Bay, Texas, USA. J Exp Mar Biol Ecol 330:119-131

Newell RC, Seiderer LJ, Hitchcock DR (1998) The impact of dredging works in coastal waters: a review of the sensitivity to disturbance and subsequent recovery of biological resources on the seabed. Oceanogr Mar Biol Ann Rev 36:127-178

765 Ohlmann JC, Niiler PP (2005) Circulation over the continental shelf in the northern Gulf of Mexico. Progr Oceanogr 64:45-81

Palmer TA, Montagna PA, Nairn RB (2008) The effects of a dredge excavation pit on benthic macrofauna in offshore Louisiana. Environ Manag, 41:573-583

Pechenik JA (2005) Biology of the invertebrates, McGray-Hill, New York

770 Peckenham JM, Thornton T, Whalen WB (2009) Sand and gravel mining: Effects on ground water resources in Hancock County, Maine, USA. Env Geol 56:1103-1114

Pempel LL, Church M (2009) Physical and ecological response to disturbance by gravel mining in a large alluvial river. Can J Fish Aquat Sci 66:52-71

Pepper DA, Stone GW (2004) Hydrodynamic and sedimentary responses to two contrasting winter storms on the inner shelf of the northern Gulf of Mexico. Mar Geol 210:43-62

Pianka ER (1970) R-Selection and K-Selection. Am Nat 104:592-597

Pinn EH, Robertson MR (2003) Macro-infaunal biodiversity and analysis of associated feeding guilds in the Greater Minch area, Scottish west coast. J Mar Biol Ass UK $83: 433-443$

780 Posey MH, Alphin TD, Banner S, Vose F, Lindberg W (1998) Temporal variability, diversity and guild structure of a benthic community in the northeastern Gulf of Mexico. Bull Mar Sci 63:143-155 
Powilleit M, Kube J (1999) Effects of severe oxygen depletion on macrobenthos in the Pomeranian Bay (southern Baltic Sea): a case study in a shallow, sublittoral habitat characterised by low species richness. J Sea Res 42:221-234

Qian PY, Chia FS (1991) Effects of food concentration on larval growth and development of two polychaete worms, Capitella capitata (Fabricius) and Polydora ligni (Webster). Bull Mar Sci 48:477-484

Rabalais NN, Smith LE, Harper Jr DE, Justic D (2001) Effects of seasonal hypoxia on continental shelf benthos. In: Rabalais NN and Turner RE (eds) Coastal hypoxia: consequences for living resources and ecosystems, coastal and estuarine studies, American Geophysical Union, Washington D.C., pp211-240

Rabalais NN, Wiseman WJ, Turner RE (1994) Comparison of continuous records of nearbottom dissolved oxygen from the hypoxia zone along the Louisiana coast. Estuaries $17: 850-861$

Rakocinski CF, LeCroy SE, McLelland JA, Heard RW (1998) Nested spatiotemporal scales of variation in sandy-shore macrobenthic community structure. Bull Mar Sci 63:343362

Rona PA (2008) The changing vision of marine minerals. Ore Geol Rev 33:618-666

800 Rosenzweig ML (1995) Species diversity in space and time, Cambridge University Press, Cambridge

Rzeznik-Orignac J, Fichet D, Boucher G (2004) Extracting massive numbers of nematodes from muddy marine deposits: efficiency and selectivity. Nematology 6:605-616

Sainte-Marie B (1990) A review of the reproductive bionomics of aquatic gammaridean amphipods. Variation of life-history traits with latitude, depth, salinity and superfamily. 7th International Colloquium on Amphipoda. Walpole, Me, pp189-227 
Shannon CE (1948) A mathematical theory of communications. Bell Sys Tech Jour 27:379423

Sheldon AL (1969) Equitability indices: dependence on the species count. Ecology 50:466$810 \quad 467$

Simpson EH (1949) Measurement of diversity. Nature 163:688

Snelgrove PVR, Butman CA (1994) Animal-sediment relationships revisited: cause versus effect. Oceanogr Mar Biol Ann Rev 32:111-177

Thouzeau G, Robert G, Ugarte R (1991) Faunal assemblages of benthic megainvertebrates inhabiting sea scallop grounds from eastern Georges Bank, in relation to environmental factors. Mar Ecol Progr Ser 74:61-82

Uebelacker JM, Johnson PG (1984) Taxonomic guide to the polychaetes of the northern Gulf of Mexico, Vol.1-7 Barry A. Vittor \& Associates, Inc., Mobile, Alabama

Van Hoey G, Degraer S, Vincx M (2004) Macrobenthic community structure of soft-bottom sediments at the Belgian continental shelf. Est Coast Shelf Sci 59:599-613

Vanaverbeke J, Deprez T, Vincx M (2007) Changes site in nematode communities at the long-term sand extraction of the Kwintebank (Southern Bight of the North Sea). Mar Pol Bull 54:1351-1360

Vanosmael C, Willems KA, Claeys D, Vincx M, Heip C (1982) Macrobenthos of a sublittoral sandbank in the southern Bight of the North Sea. J Mar Biol Ass UK 62:521-534

Wheatcroft RA, Sommerfield CK (2005) River sediment flux and shelf sediment accumulation rates on the Pacific Northwest margin. Cont Shelf Res 25:311-332

Whittaker RH (1972) Evolution and measurement of species diversity. Taxon 21:213-251

Wu RSS, Or YY (2005) Bioenergetics, growth and reproduction of amphipods are affected by moderately low oxygen regimes. Mar Ecol Progr Ser 297:215-223

Yonge CM, Thompson TE (1976) Living marine molluscs, Collins, St James Place, London 
Zeppelini D, Bellini BC, Creato-Duarte AJ (2009) Collembola as bioindicators of restoration in mined sand dunes of Northeastern Brazil. Biodiv Conserv 18:1161-1170

Zühlke R (2001) Polychaete tubes create ephemeral community patterns: Lanice conchilega (Pallas, 1766) associations studied over six years. J Sea Res 46:261-272 


\section{Figure captions}

Figure 1. Geographic position of the 21 sampling stations on Ship Shoal, off Louisiana. Detailled bathymetry outlining the shoal and surrounding area is given. Depths in meters (m). Coordinates in NTF (system) Lambert (projection). Data for the bathymetry provided by Divins D.L. and Metzger D., National Geophysical Data Center (NOAA) http://www.ngdc.noaa.gov/mgg/coastal/coastal.html

Figure 2. Seasonal variations in abundances (individuals $\mathrm{m}^{-2}$; mean $\pm \mathrm{SE}$ ) of main taxonomic groups, with emphasis on spionids and amphipods. Core cross-sectional area $=0.09$ $\mathrm{m}^{2}$.

Figure 3. Mean biomass (wet weight; $\mathrm{g} \mathrm{m}^{-2}$; mean $\pm \mathrm{SE}$ ) of polychaetes, mollusks (including shells) and other taxonomic groups according to seasonality. Core cross-sectional area $=0.09 \mathrm{~m}^{2}$. Letters $\mathrm{a}, \mathrm{b}$ and $\mathrm{c}$ refers to statistical differences between the 3 seasons for total biomass, polychaetes, mollusks and others.

Figure 4. Global and mean ( \pm SE) species richness in spring on Ship Shoal within the east, middle and west transects on the Ship Shoal. Core cross-sectional area $=0.09 \mathrm{~m}^{2}$. See Figure 1 for precise location of the stations.

855 Figure 5. Multi-dimensional scaling ordination diagram of all samples of all stations showing seasonal changes in species composition and assemblages. Ordination was based on unstandardized log-transformed abundances matrix.

Figure 6. Multi-dimensional scaling ordination diagrams based showing, for spring (top), summer (middle) and autumn (bottom) samples east-west variations (left panels) or north-south variations (right panels). A schematic of the shoal is provided to illustrate the position of the stations on the east-west and north-south transects (see Figure 1 and 
description of study site for details). Ordination was based on unstandardized logtransformed abundances matrix.

Figure 7. Seasonal variations in dominance (\%) of the five feeding guilds. Interface feeders are species which can switch between suspension-feeding and surface deposit-feeding. 
5870 Table 1. Species richness and heterogeneity of diversity and equitability (mean \pm SE) for 6 measurement, where same letters indicate non-significant differences at $p$-level $=0.05$

\begin{tabular}{lccccc}
\hline & $\begin{array}{c}\text { Seasonal } \\
\text { global } \\
\text { species } \\
\text { richness }\end{array}$ & $\begin{array}{c}\text { Species } \\
\text { Richness }\end{array}$ & $\begin{array}{c}\text { Heterogeneity of } \\
\text { diversity N1 = exp } \\
\left(\mathrm{H}^{\prime}\right)\end{array}$ & $\begin{array}{c}\text { Heterogeneity of } \\
\text { diversity N2 }= \\
1 / \mathrm{SI}\end{array}$ & Equitability J' \\
\hline Spring & 134 & $33.19 \pm 1.53^{\mathrm{a}}$ & $13.90 \pm 1.15^{\mathrm{a}}$ & $8.67 \pm 0.86$ & $0.72 \pm 0.10$ \\
Summer & 118 & $23.71 \pm 1.05^{\mathrm{b}}$ & $12.40 \pm 0.96^{\mathrm{a}}$ & $8.19 \pm 0.73$ & $0.77 \pm 0.08$ \\
Autumn & 91 & $13.54 \pm 1.01^{\mathrm{c}}$ & $8.38 \pm 0.80^{\mathrm{b}}$ & $6.08 \pm 0.58$ & $0.78 \pm 0.11$
\end{tabular}


Table 2. Results of ANOVA tests showing east-west gradient and north-south gradient within Ship Shoal area according to diversity indices, species abundance and biomass for each season. $\mathrm{SR}=$ species richness (N0), N1 and N2 $=$ heterogeneity of diversity. Post-hoc 880 columns indicated results of post-hoc comparisons between E (east), M (middle) and W (west) or between $\mathrm{N}$ (north), M (middle) and S (south), with " = " indicating non-significant difference and " $<$ " indicating significant difference at $p$-level $=0.05$

\begin{tabular}{lcccccc}
\hline \multicolumn{1}{c}{ Spring } & \multicolumn{3}{c}{ east - west gradient } & \multicolumn{3}{c}{ north - south gradient } \\
& $\mathrm{F}$ & p-level & post-hoc & $\mathrm{F}$ & p-level & post-hoc \\
\hline $\mathrm{SR}$ & 2.91 & $\mathrm{NS}$ & - & 4.27 & 0.032 & $\mathrm{~N}=\mathrm{M}<\mathrm{S}$ \\
$\mathrm{N} 1$ & 18.35 & $7.210^{-5}$ & $\mathrm{E}<\mathrm{M}<\mathrm{W}$ & 5.91 & 0.012 & $\mathrm{~N}<\mathrm{M}<\mathrm{S}$ \\
$\mathrm{N} 2$ & 13.05 & $4.010^{-4}$ & $\mathrm{E}<\mathrm{M}<\mathrm{W}$ & 4.41 & 0.029 & $\mathrm{~N}<\mathrm{M}=\mathrm{S}$ \\
abundances & 13.06 & $4.010^{-3}$ & $\mathrm{E}=\mathrm{M}<\mathrm{W}$ & 5.19 & 0.018 & $\mathrm{~N}<\mathrm{M}=\mathrm{S}$ \\
total biomass & 1.07 & $\mathrm{NS}$ & - & 2.09 & $\mathrm{NS}$ & - \\
polychaete biomass & 5.77 & 0.013 & $\mathrm{E}<\mathrm{M}=\mathrm{W}$ & 39.29 & $1.010^{-7}$ & $\mathrm{~N}=\mathrm{M}<\mathrm{S}$
\end{tabular}

\begin{tabular}{lcccccc}
\hline \multicolumn{1}{c}{ Summer } & \multicolumn{3}{c}{ east - west gradient } & \multicolumn{3}{c}{ north - south gradient } \\
& $\mathrm{F}$ & p-level & post-hoc & $\mathrm{F}$ & p-level & post-hoc \\
\hline $\mathrm{SR}$ & 2.85 & $\mathrm{NS}$ & - & 8.83 & 0.002 & $\mathrm{~N}<\mathrm{M}<\mathrm{S}$ \\
$\mathrm{N} 1$ & 1.52 & $\mathrm{NS}$ & - & 11.40 & $610^{-4}$ & $\mathrm{~N}=\mathrm{M}<\mathrm{S}$ \\
$\mathrm{N} 2$ & 3.17 & $\mathrm{NS}$ & - & 15.04 & $4.410^{-6}$ & $\mathrm{~N}=\mathrm{M}<\mathrm{S}$ \\
abundances & 58.82 & $110^{-6}$ & $\mathrm{E}<\mathrm{M}<\mathrm{W}$ & 37.42 & $110^{-6}$ & $\mathrm{~N}<\mathrm{M}<\mathrm{S}$ \\
total biomass & 2.13 & $\mathrm{NS}$ & - & 0.15 & $\mathrm{NS}$ & - \\
polychaete biomass & 4.47 & 0.026 & $\mathrm{E}=\mathrm{M}<\mathrm{W}$ & 13.15 & $310^{-4}$ & $\mathrm{~N}=\mathrm{M}<\mathrm{S}$ \\
& & & & & &
\end{tabular}

\begin{tabular}{lcccccc}
\hline \multicolumn{1}{c}{ Autumn } & \multicolumn{3}{c}{ east - west gradient } & \multicolumn{3}{c}{ north - south gradient } \\
& $\mathrm{F}$ & $\mathrm{p}$-level & post-hoc & $\mathrm{F}$ & p-level & post-hoc \\
\hline $\mathrm{SR}$ & 11.32 & $6.5410^{-4}$ & $\mathrm{E}=\mathrm{M}<\mathrm{W}$ & 4.26 & 0.030 & $\mathrm{~N}=\mathrm{M}<\mathrm{S}$ \\
$\mathrm{N} 1$ & 2.80 & $\mathrm{NS}$ & - & 1.93 & $\mathrm{NS}$ & - \\
$\mathrm{N} 2$ & 1.11 & $\mathrm{NS}$ & - & 1.16 & $\mathrm{NS}$ & - \\
abundances & 15.71 & $1.1310^{-4}$ & $\mathrm{E}<\mathrm{M}<\mathrm{W}$ & 9.39 & $1.1610^{-4}$ & $\mathrm{~N}<\mathrm{M}<\mathrm{S}$ \\
total biomass & 0.47 & $\mathrm{NS}$ & - & 1.15 & $\mathrm{NS}$ & - \\
polychaete biomass & 0.06 & $\mathrm{NS}$ & - & 0.06 & $\mathrm{NS}$ & -
\end{tabular}


1

Table 3. Seasonal variations in monitored environmental parameters over Ship Shoal

\begin{tabular}{lcccccc}
\hline & \multicolumn{2}{c}{ Spring } & \multicolumn{2}{c}{ Summer } & \multicolumn{2}{c}{ Autumn } \\
& $\min -\max$ & $\operatorname{mean} \pm \mathrm{sd}$ & $\min -\max$ & $\operatorname{mean} \pm \mathrm{sd}$ & $\min -\max$ & $\operatorname{mean} \pm \mathrm{sd}$ \\
\hline Depth $(\mathrm{m})$ & $4.2-10.2$ & $6.9 \pm 1.6$ & $4.2-9.4$ & $6.4 \pm 1.5$ & $4.9-10.5$ & $7.2 \pm 1.7$ \\
Mean grain size $(\mu \mathrm{m})$ & $127.7-198.1$ & $159.9 \pm 20.6$ & $118.1-323.3$ & $170.0 \pm 39.5$ & $115.6-320.6$ & $174.3 \pm 46.2$ \\
Silt/clay content $(\%)$ & $0.3-3.4$ & $1.4 \pm 1.0$ & $0.3-4.5$ & $1.4 \pm 1.1$ & $0.3-18.1$ & $1.9 \pm 4.2$ \\
Gravel content $(\%)$ & $0.0-3.7$ & $0.5 \pm 1.0$ & $0.1-11$ & $1.2 \pm 2.6$ & $0.1-11.8$ & $1.4 \pm 3.1$ \\
Sorting index & $1.2-1.7$ & $1.2 \pm 0.1$ & $1.2-2.5$ & $1.3 \pm 0.3$ & $1.3-2.4$ & $1.3 \pm 0.3$ \\
Chlorophyl $a\left(\mathrm{mg} \mathrm{m}^{-2}\right)$ & $12.0-120.1$ & $41.8 \pm 27.4$ & $2.7-122.0$ & $37.0 \pm 31.5$ & $1.8-94.0$ & $30.2 \pm 21.8$ \\
Dissolved oxygen $\left(\mathrm{mg} \mathrm{L}^{-1}\right)$ & $2.0-8.4$ & $6.1 \pm 1.5$ & $4.5-8.3$ & $6.3 \pm 1.1$ & $6.3-7.2$ & $6.9 \pm 0.3$
\end{tabular}


1

Table 4. ANOSIM and SIMPER results comparing species composition according to seasons. Core cross-sectional area $=0.09 \mathrm{~m}^{2}$. SIMPER cumulative dissimilarity cut-off $=50 \%$. See Figure 6 for nMDS plots

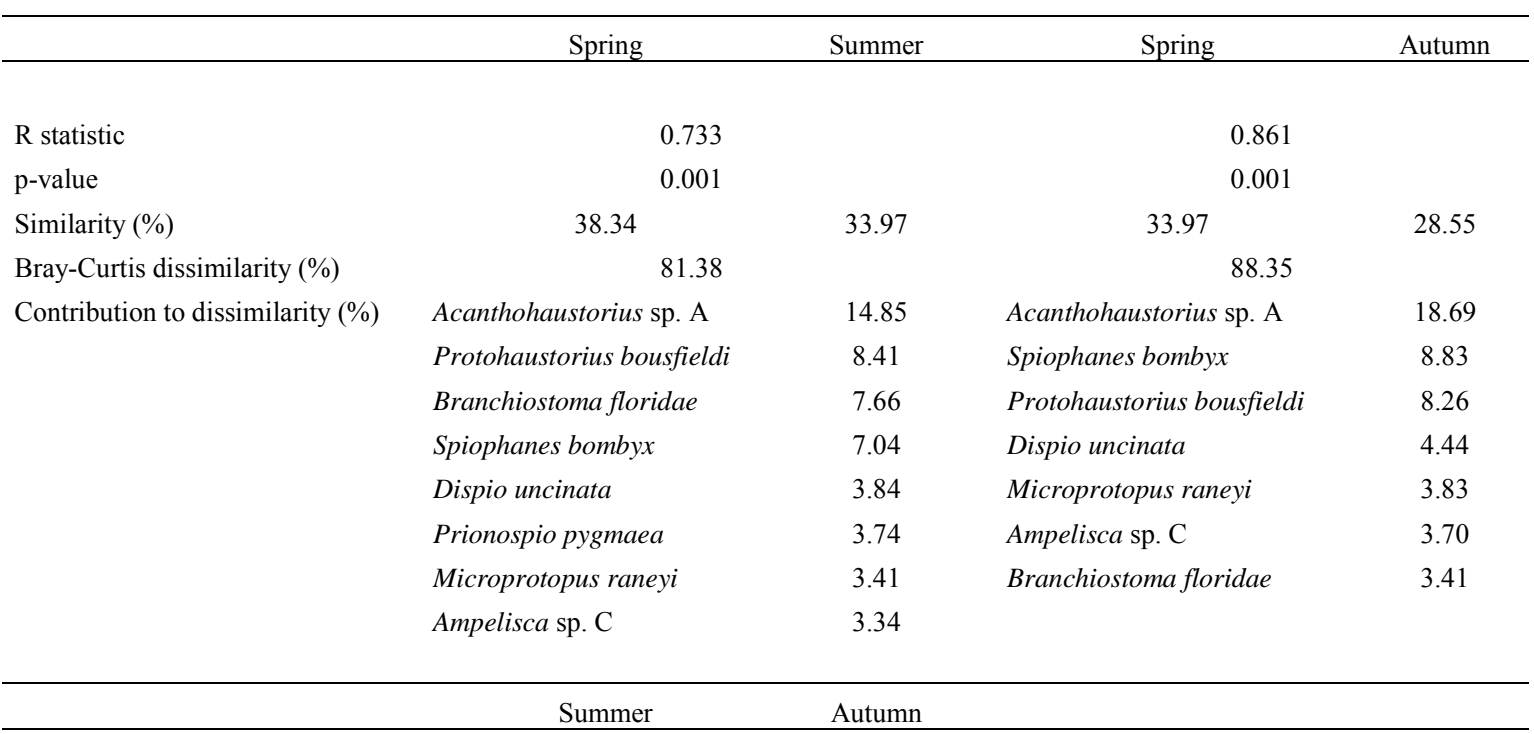

\section{R statistic}

p-value

Similarity (\%)

Bray-Curtis dissimilarity (\%)

Contribution to dissimilarity (\%)

\begin{tabular}{|c|c|}
\hline 0.459 & \\
\hline 0.001 & \\
\hline 33.97 & 28.55 \\
\hline 76.70 & \\
\hline Branchiostoma floridae & 16.12 \\
\hline Acanthohaustorius sp. A & 10.51 \\
\hline Prionospio pygmaea & 9.18 \\
\hline Protohaustorius bousfieldi & 6.37 \\
\hline Scoloplos sp.B & 3.82 \\
\hline Mediomastus californiensis & 2.86 \\
\hline Magelona sp.A & 2.64 \\
\hline
\end{tabular}




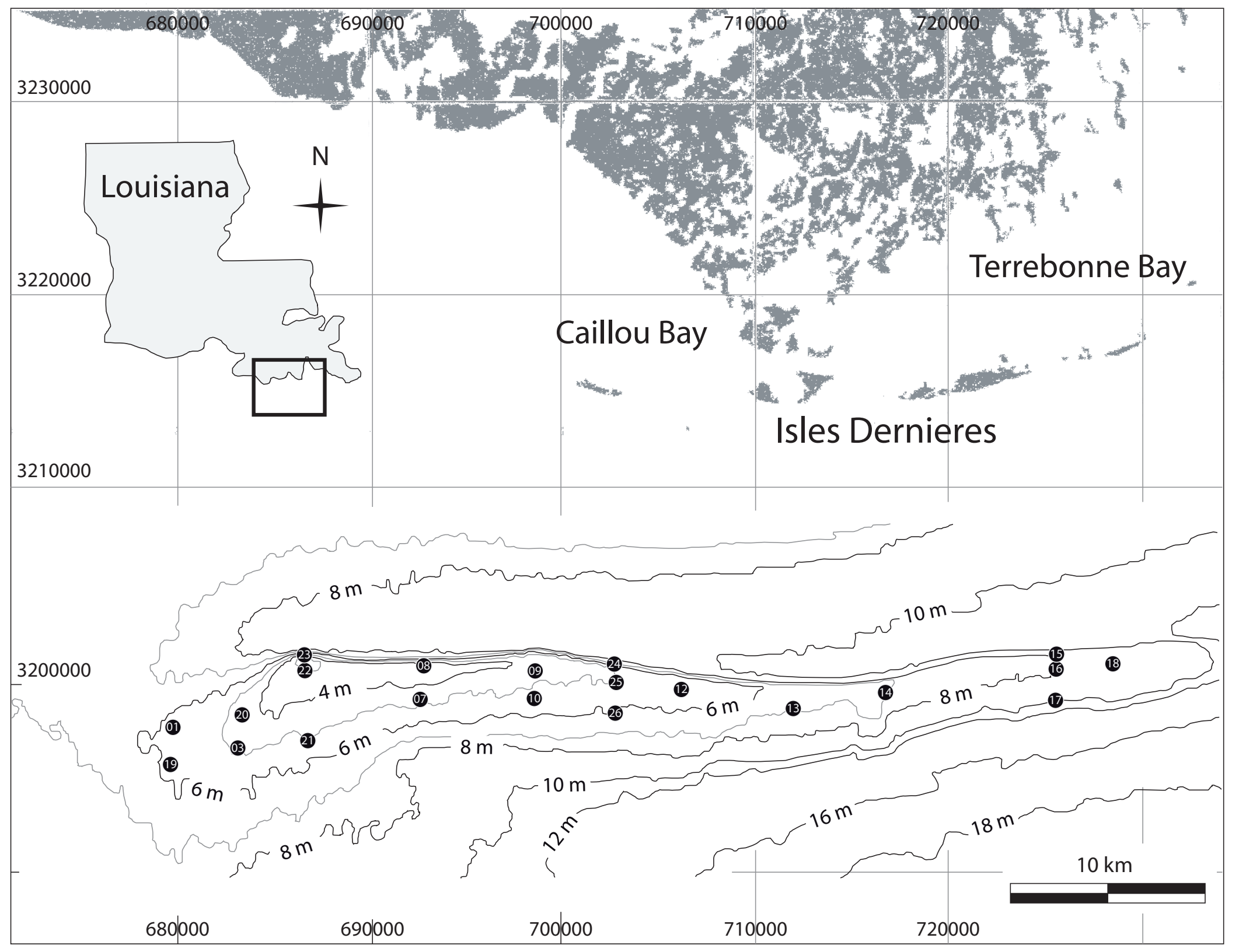




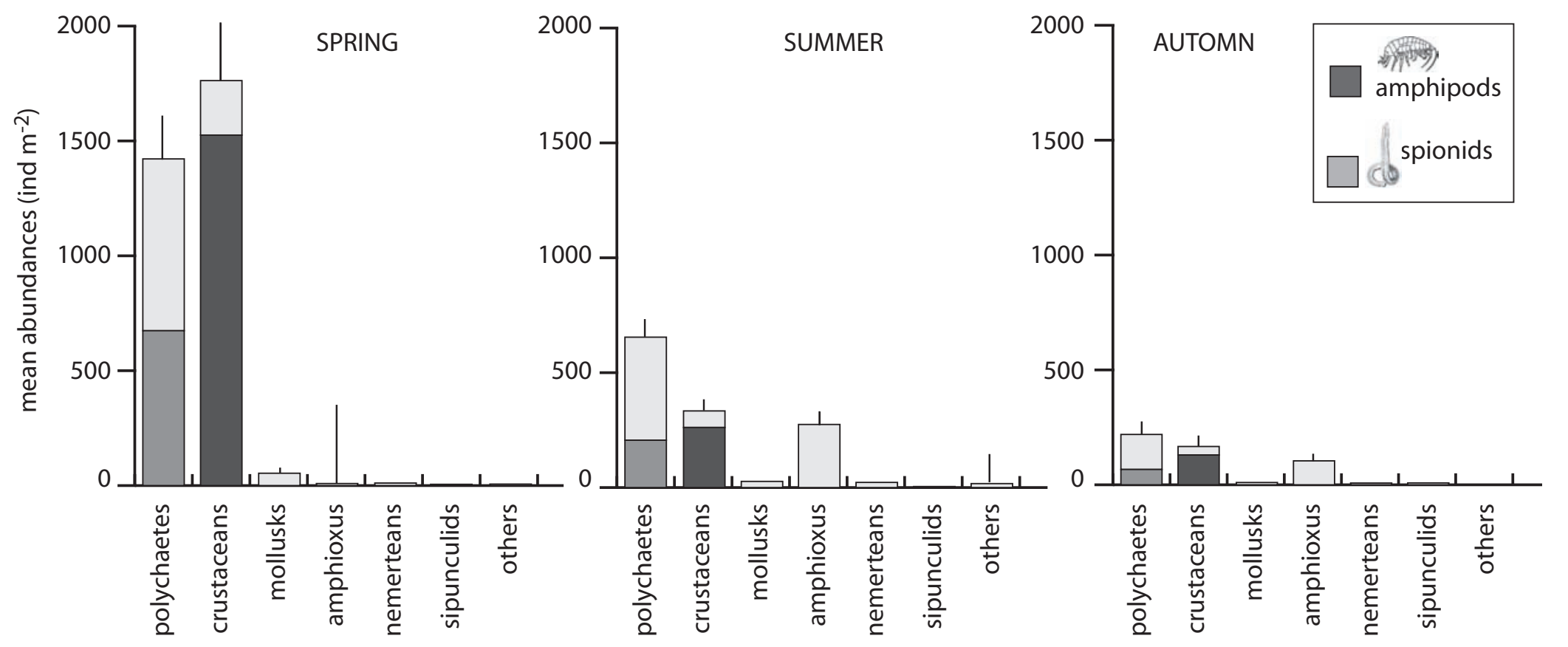




\section{Ine figure 3}

Click here to download line figure: Fig 3review.eps

?
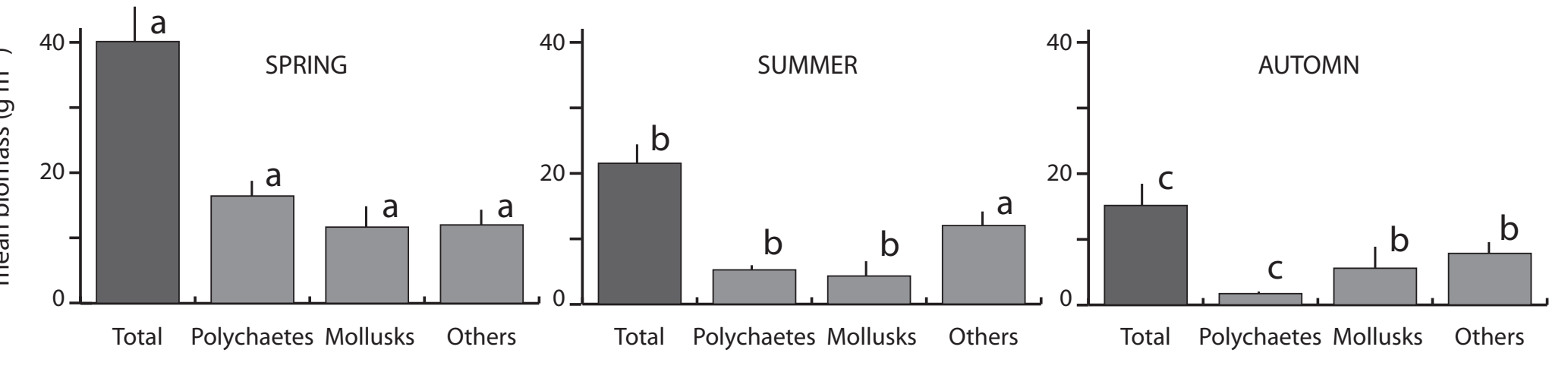


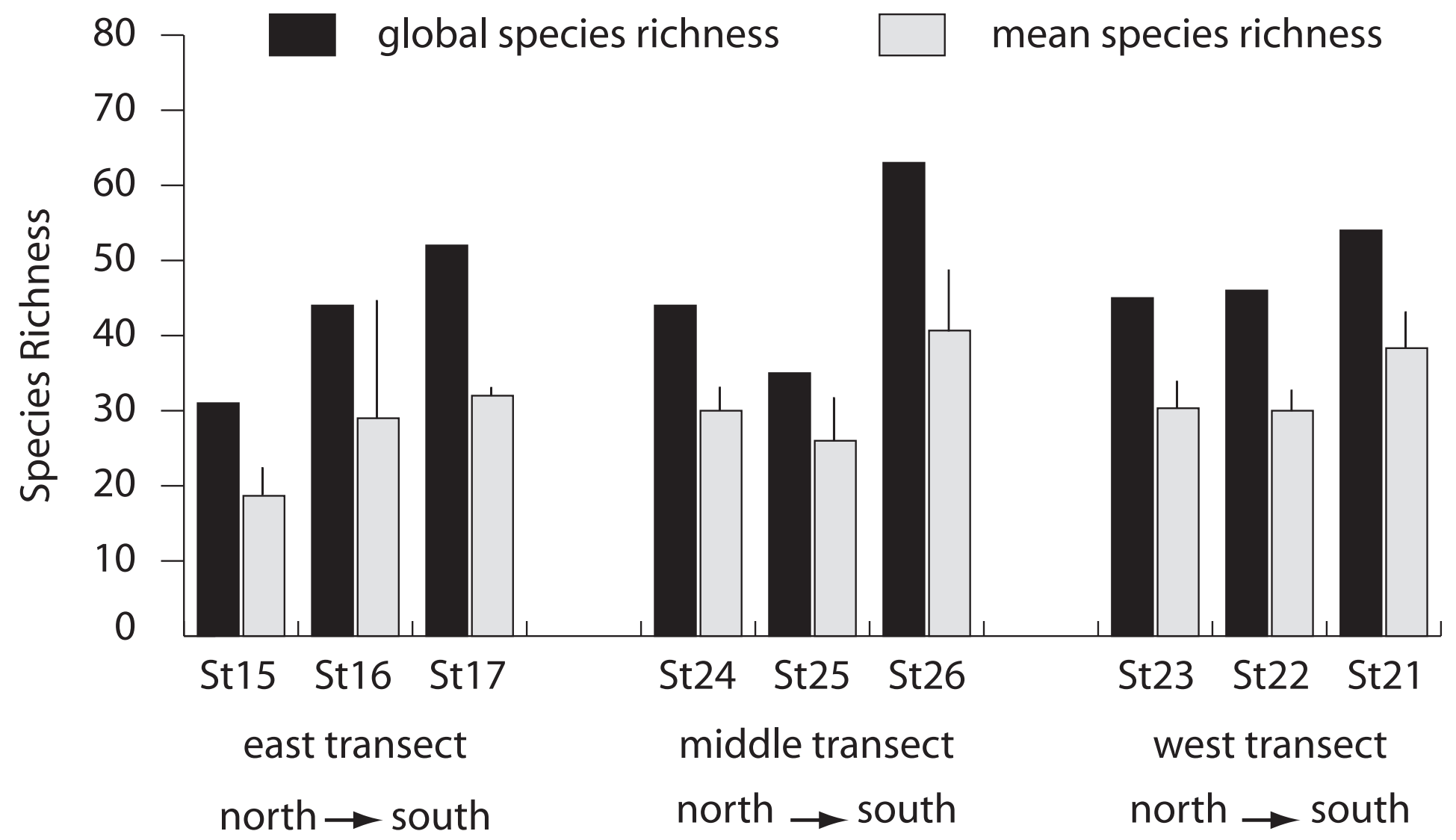


line figure 5
Click here to download line figure: Fig 5review.eps

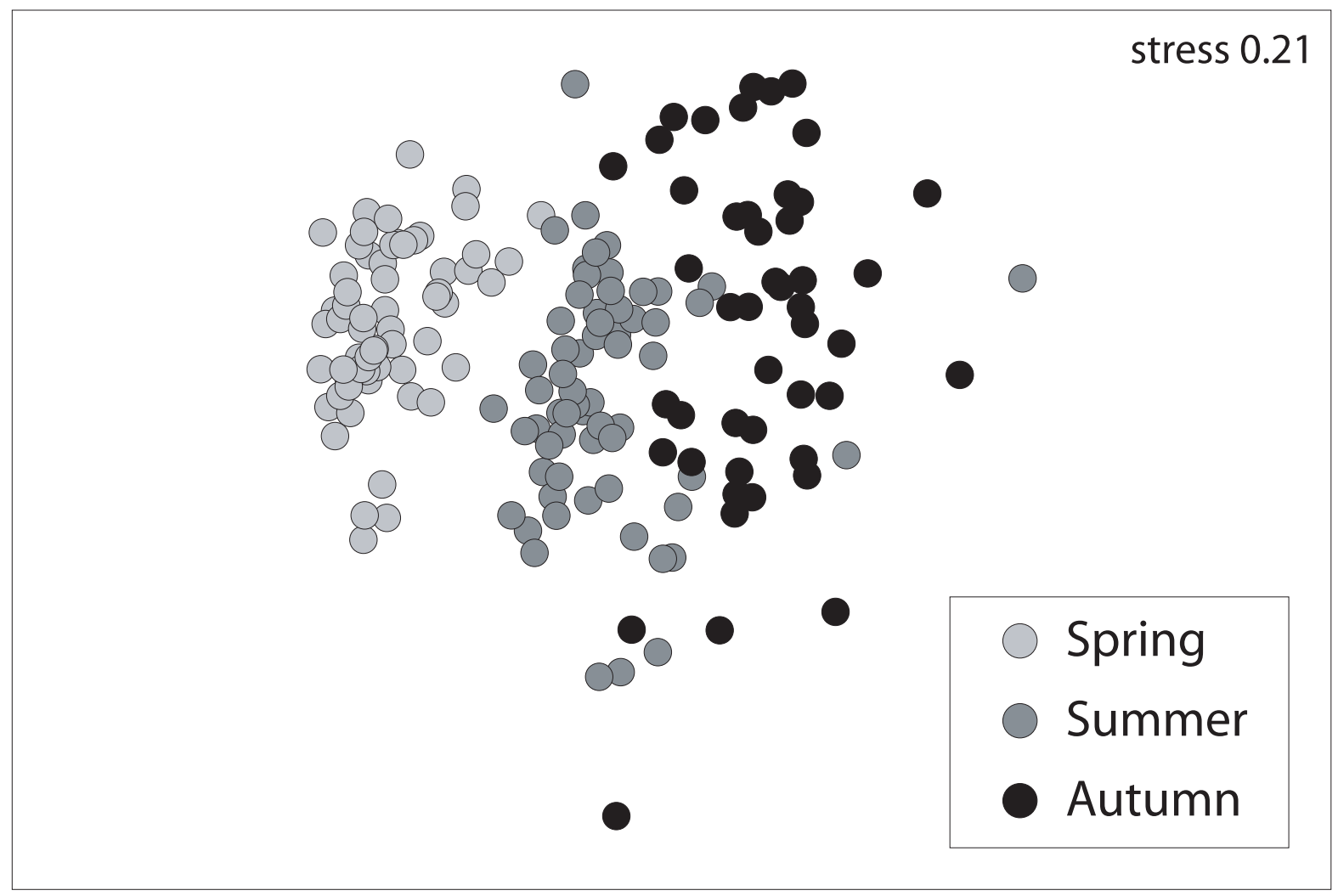


West East Middle

\section{Spring}

stress $=0.16$

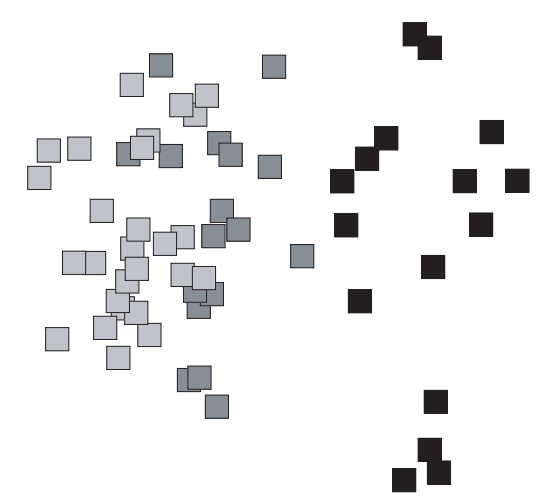

\section{Summer}

stress $=0.20$

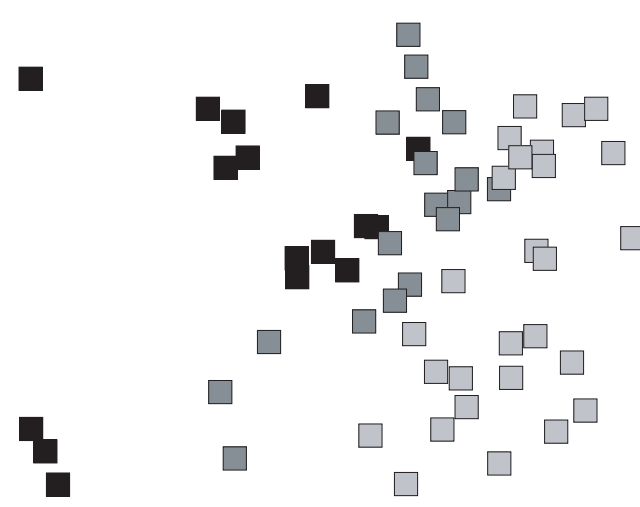

Autumn

stress $=0.23$

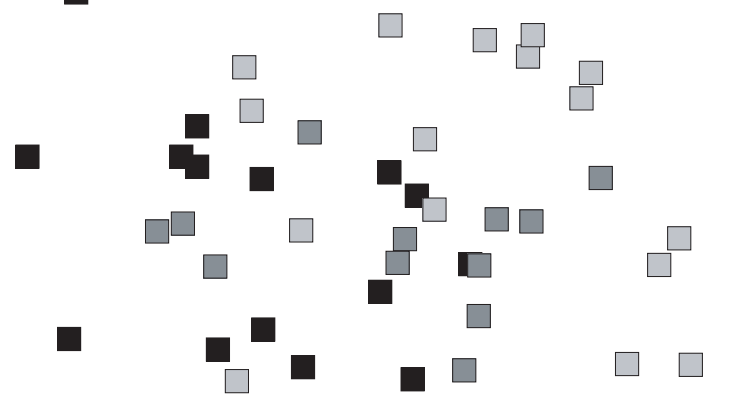
A North $\bigcirc$ Middle
$\nabla$ South
88
$88 \div 0$ o 8 unlabelled

\section{Spring}

stress $=0.16$

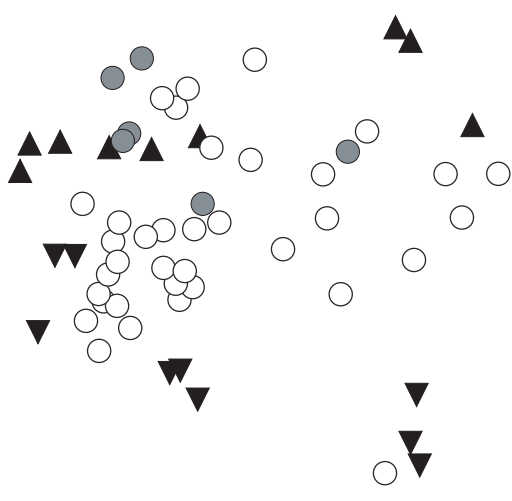

Summer

stress $=0.20$

$\Delta$

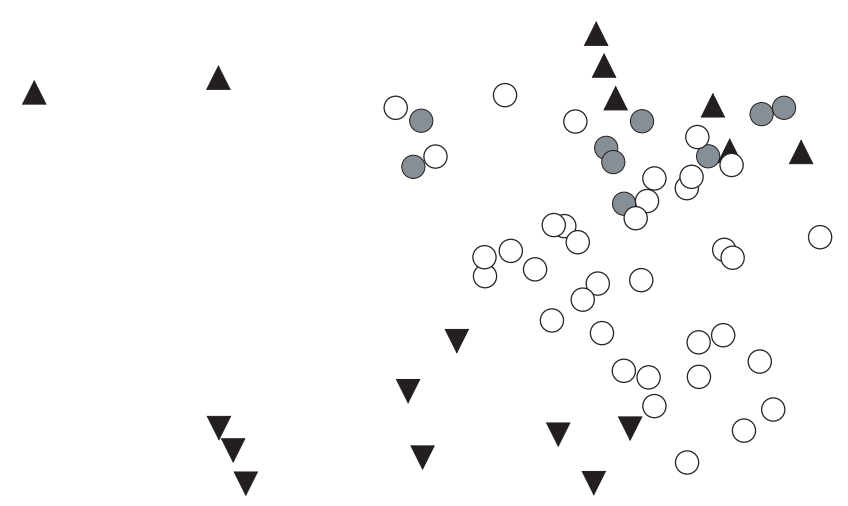

$\Delta$
Autumn

stress $=0.23$

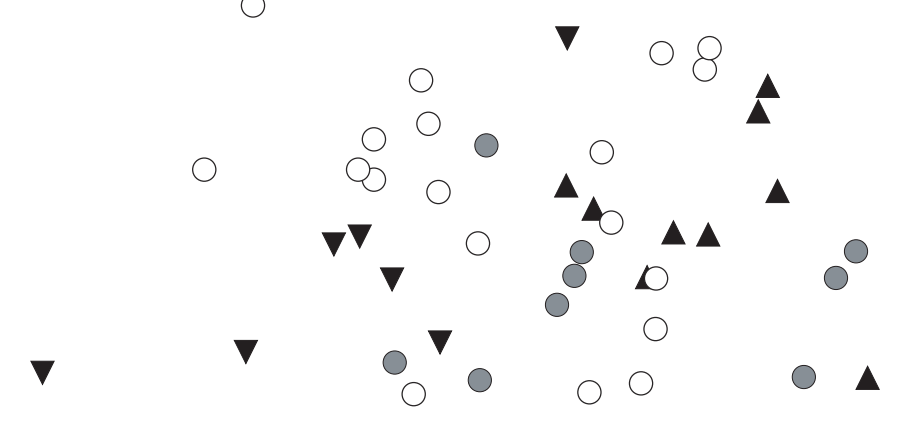


suspension-feeders

$\square$ surface deposit-feeders

$\square$ interface feeders sub-surface deposit-feeders

predators / scavengers

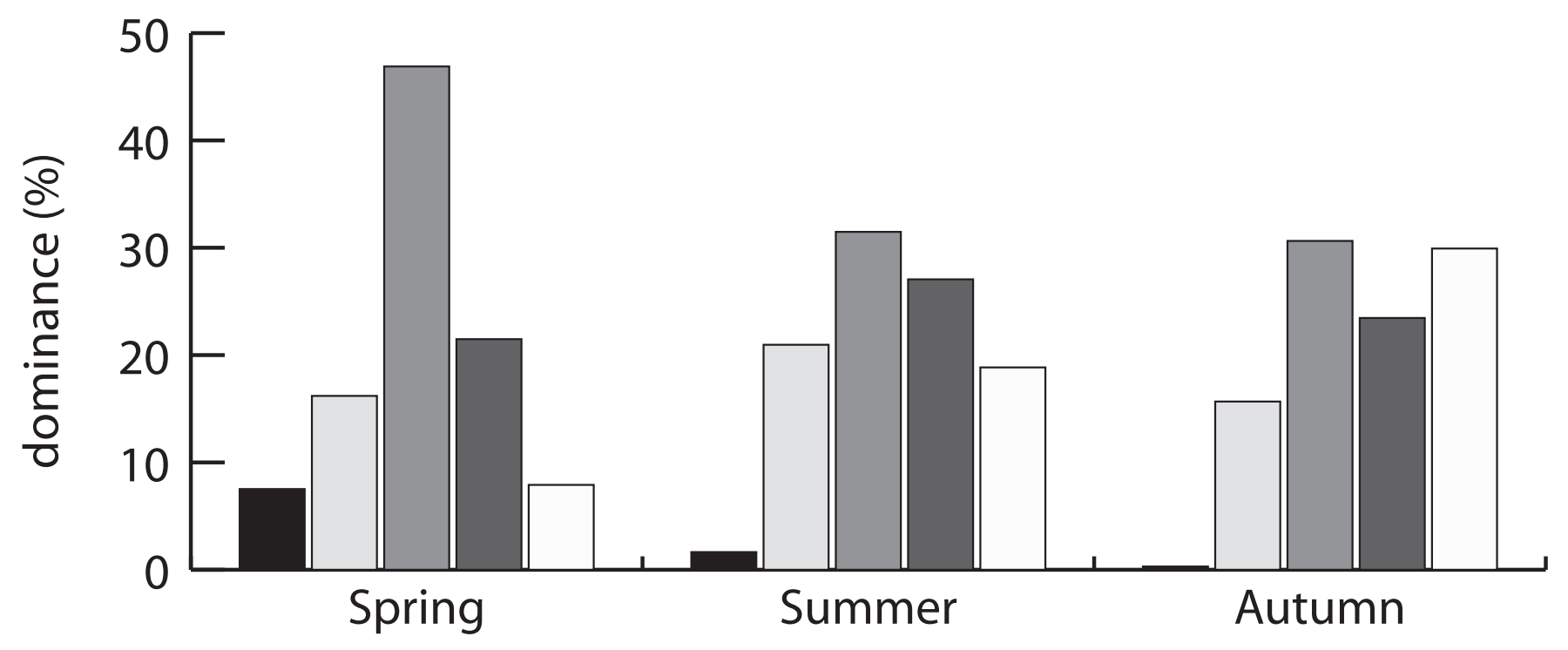

